\title{
The Use of Metal Nanoparticles to Produce Yellow, Red and Iridescent Colour, from Bronze Age to Present Times in Lustre Pottery and Glass: Solid State Chemistry, Spectroscopy and Nanostructure
}

\author{
Philippe Colomban ${ }^{1, a}$ \\ ${ }^{1}$ Laboratoire de Dynamique, Interactions et Réactivité - UMR7075 CNRS \\ Université Pierre et Marie Curie (UPMC) \\ 2 rue Henry Dunant, 94320 Thiais, France \\ aphilippe.colomban@glvt-cnrs.fr
}

Received: July 7, 2008; February 13, 2009; accepted: February 20, 2009

Keywords: nanoparticle, silver, gold, copper, lustre, glass, glaze, pottery, Raman scattering

\begin{abstract}
The use of metal nanoparticles dispersed in an optically clear matrix by potters and glassmakers from the Bronze Age up to the present time is reviewed from the solid state chemistry and material science point of view. The nature of metal (gold, silver or copper), the importance of some other elements ( $\mathrm{Fe}, \mathrm{Sn}, \mathrm{Sb}, \mathrm{Bi}$ ) added to control metal reduction in the glass in relation to the firing atmosphere (combined reducing oxidizing sequences, role of hydrogen and water) are considered in the light of ancient Treatises and recent analyses using advanced techniques (FIBTEM, EXAFS,...) and classical methods (optical microscopy, UV-visible absorption). The different types of colour production, by absorption/reflection (red, yellow) or diffraction (iridescence) and the relationship between nanostructure (metal particle dispersion, layer stacking) and lustre colour are discussed. The very specific interaction between light and the metal nanoparticle makes Raman scattering a very useful "bottom up" technique to study the local glass structure around the metal particles as well as to detect incomplete metal reduction or residues tracing the preparation route, hence making it possible to differentiate between genuine artefacts and fakes.
\end{abstract}

\section{Introduction}

Potters have been using nanomaterials, namely clays, for more than 17000 years: most of the properties of traditional ceramics (notably a good shapability, low sintering temperatures and low production costs) stem from the fact that their raw materials -natural clays- are nanosized [1]: the water molecules lubricate the sliding of the clay nanoslabs against each other and the rheology is pH controlled; the nanometric size promotes ion diffusion, and hence reactivity and sintering. SolGel routes mimic clay technology and extend its advantages to a variety of non-silicate compositions [1,2]. The invention of Ceramic Matrix Composites (CMCs) is also very old and derives its properties from natural nanosized mineral, asbestos, a rock yarn made of $\sim 10 \mathrm{~nm}$ diameter flexible fibres. The invention dates back to the Iron Age, in Corsica: women potters prepared utensils for cooking with a mixture of long asbestos yarns and clays [3]. The interest in this ancient technology is also old: for instance the first scientific study of these CMC materials was undertaken in 1838-1839 by A. Brongniart, the famous ceramist, glassmaker and solid state chemist who established the French National Ceramic Museum at Sèvres.

A new generation of engineered nanomaterials (grain size $<100 \mathrm{~nm}$ ) has been in development - if not already commercially available - for the last twenty years. Reducing the dimension of matter domains down to the nanometre scale confines the electronic and vibrational wave functions, which results in unique properties and opens a wide range of potential applications in different domains such as: i) optics and microwaves : pigments for the cosmetic industry, fluorescent markers and quantum dots, photonic crystals (multiplexing and switching in optical networks), quantum 
computer components, light emitting devices, paints, coatings and materials for radar stealthiness properties, etc.; ii) mechanics : cutting tools, wear-resistant and anti-corrosion coatings, "nanopolishing" powders, fibre-reinforced composites, structural nanocomposites, etc.; iii) microelectronic and -ionic devices : miniaturized silicon chips, single electron transistors, relaxor ferroelectrics carbon or silicon nanotube transistors, batteries, supercapacitors, solar cells, etc.; iv) magnetic devices : data storage, reading heads and giant magneto-resistances, radar wave signature etc.; v) reactivity : improved combustion of fuel-rich propellants, filters, nanosensors, catalysts, etc. and vi) biocompatibility : in vivo drug delivery, diagnostic and monitoring devices, etc., see references in [4]. Actually, nanocomposite materials formed by semiconductors or metal nanoclusters embedded in an optically clear, dielectric matrix have been produced for centuries. Because of the human eye sharpness, the particle size of pigments must be smaller than $10 \mu \mathrm{m}$ to homogeneously colour enamels and glasses and ultrafine powders $(<0.1 \mu \mathrm{m})$ prepared for centuries to obtain special colour (e.g. orange with haematite). Outstanding optical properties can be obtained. For example, the $4^{\text {th }}$ century Roman Lycurgus cup, presently in the British Museum, appears wine red when viewed in transmitted light, but green in reflected light. This dichroic colouring is attributed to nanocrystals of a $\mathrm{Au} / \mathrm{Ag}$ alloy (and likely $\mathrm{Cu}$ ) dispersed throughout the glassy matrix [5,6]; the role of $\mathrm{Cu}$ metal nanoparticles will be further discussed in more detail. Hematinum red glass cups were first described by the Roman historian Pliny the Elder, as reported in ref [7]. Actually most of the red tesserae used in Roman mosaics are made of glass with a dispersion of $\mathrm{Cu}^{\circ}$ nanocrystals $[8,9]$ and this technique was used quasi continuously up to present times [7,10-12]. The huge number of mosaic tesserae is due to a quasi industrial production of glass ingots during Roman times. It was reported that some red tesserae contain both copper and gold [8], as for the Lycurgus cup. The presence of both $\mathrm{Cu}^{\circ}$ particles and cuprous oxide $\left(\right.$ cuprite $\left.\mathrm{Cu}_{2} \mathrm{O}\right)$ was also recognized in Celtic enamels [13] and, likely, in some $19^{\text {th }}$ Dynasty Egyptian glass [14]. Recently it was confirmed that red glass coloured by $\mathrm{Cu}^{\circ}$ nanoparticles dates from the European Bronze Age [15]. The technique was worldwide used. For instance, Satsuma Japanese glasses were also coloured with copper [16] and fired in reducing conditions. A similar technique gives rise to the red flambé and mixed blue-red Jun glazed porcelains from middle-aged Song and Ming to Qing Chinese Dynasties [17-18] as well as some Vietnamese porcelains and stonewares [19]. Nature itself produces glasses with a natural metallic sheen [20].

The purpose of this paper is to present a review on the use of metal nanoparticles by potters and glassmakers and to give the recent state of the art, achievements on the solid state physics and chemistry of iridescent materials giving rise to the lustre sheen (Fig. 1 \& Table 1). Emphasis is given to the characterisation by Transmission Electron Microscopy and by Raman Scattering, two techniques among the most appropriate for the studied materials. A link will be made with advanced materials developed for optical devices (photonic crystal).

\section{Lustre glass and pottery}

Some glasses and ceramics have a more or less metallic sheen and are called lustre ceramics and glasses. The definition of lustre was rather broad and in ancient Treatises, the differentiation between gilding and lustre is not clear (Table 2). We will understand why when discussing the TEM images. When a lustre pottery is illuminated with white light, the colour varies according to the relative angle between the light source, the pottery surface and the observer, similar as for opals, some butterfly wings and scarab beetles or compact disks that are all materials made from a more or less periodic 3D array of nanoparticles with specific optical properties. The regularity of the array is required for a good selection of the iridescence, at the specular angle, as for the well-known Bragg equation in Crystallography [21, 22]: the diffraction by poor quality networks, e.g. disordered crystals received attention and appropriate theory is reported in textbooks related to X-ray diffraction [23] or to the physics of the colour [24]. Alternatively the Mie theory can also be used.

The technique of heating glass, coated with a silver-based precursor is assigned to Coptic glassmakers in Egypt (and/or to Syrian glassmakers?) in the sixth or seventh century [25-27] . It is 

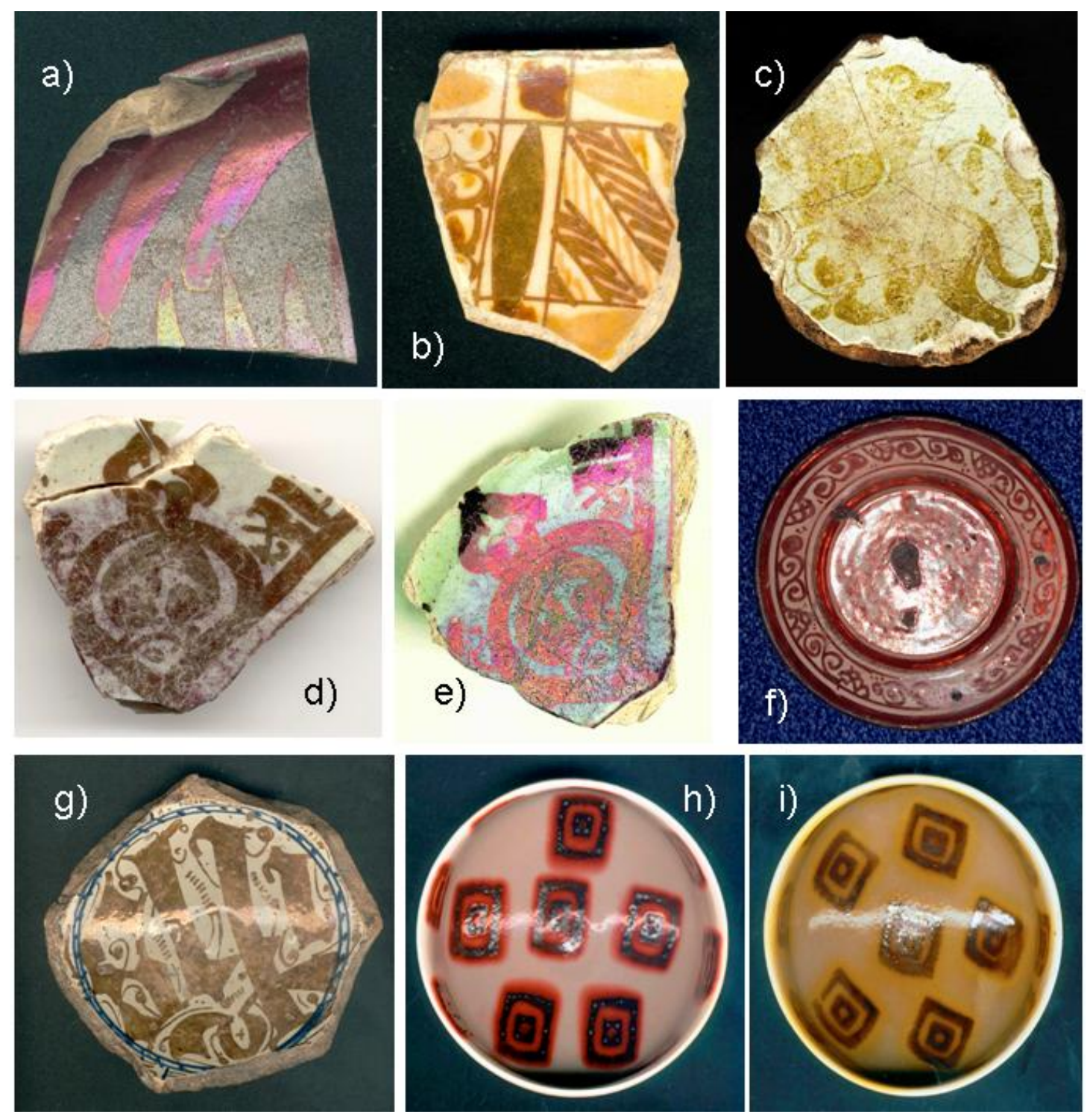

Fig. 1 : Examples of lustre potteries : a \& b) polychrome shards from Suse (Abbasid, $9^{\text {th }}$ century), c - e) Fatimid shards depicting a lion or a leopard (c) and a palmette (d, e) both excavated from Fustat $\left(12^{\text {th }}\right.$ century, Cairo, Egypt); for the later shard two orientations are shown; f) red HispanoMoresque and g) Mudejar (16 ${ }^{\text {th }}$ century, Andalusia) potteries (Sèvres Museum Collection); the later depicts the Latin HIS inscription, Iesus Humanitas Salvator, and after $180^{\mathrm{d}}$ turn, an Arabic one, almulk, the Kingdom; h) and i) are modern red and gold shine lustres from Eva Hundum. (Photograph, Ph. Colomban). Dimensions: a,b,d-e $\sim 5 \times 5 \mathrm{~cm}^{2}, \mathrm{c}, \mathrm{g}, \mathrm{h}, \mathrm{I} \sim \operatorname{diameter} \sim 12 \mathrm{~cm}$, f diameter $\sim 20 \mathrm{~cm}$.

however reported that Buontalenti, the famous glassmaker and potter of the Medici Dukes, reported that the colour of Roman alassonti vases changes with the observation angle [7]. This remark is consistent with the production of lustre glasses before Islamic Times, but, to our knowledge, no dated artefact has been found and analysed. Actually, known lustre glasses do not exhibit such a strong metallic shine as observed for lustre pottery (Figs $1 \& 2$ ), which questions the relationship between their preparation techniques and their micro/nanostructures.

Incorporation of elemental $\mathrm{Ag}$ at the glass surface from a precursor ("cementation") remains the usual way to obtain yellow coloured stained glass windows from the Middle Ages through the Renaissance to present times $[7,11,12,28]$. The production of red stained glasses by flashing/coating thin films (30 to $500 \mu \mathrm{m}$ ) of a $\mathrm{Cu}^{\circ}$-rich glass (Fig. 2) over a colourless glass is also dated from the Middle-Ages [29]. The very strong absorption of the light by the metal-containing film requires very thin layers of metal-containing glass (Fig. 3). 
Table 1: Origin and date of studied artefacts.

\begin{tabular}{|c|c|c|}
\hline $\begin{array}{c}\text { Artefact } \\
\text { Origin } \\
\end{array}$ & Period & References \\
\hline Mesopotamia & $9^{\text {th }}$ & Padovani et al. 2006 [87] \\
\hline \multirow[t]{3}{*}{ Middle-East } & “ & Roqué et al. 2006 [43] \\
\hline & $9^{\text {th }}$ & Bobin et al. 2003 [57] \\
\hline & $10^{\text {th }}-13^{\text {th }}$ & “ \\
\hline Egypt. & $12^{\text {th }}-14^{\text {th }}$ & $\begin{array}{l}\text { Mirguet et al. } 2008[22] \\
\text { Colomban \& Truong } 2004\end{array}$ \\
\hline \multirow{2}{*}{$\begin{array}{l}\text { Iran } \\
\text { Sicily }\end{array}$} & $10^{\text {th }}-13^{\text {th }}$ & Borgia et al. 2004 [40] \\
\hline & & Bobin et al. 2003 [58] \\
\hline \multirow{4}{*}{$\begin{array}{l}\text { Iberian } \\
\text { Peninsula }\end{array}$} & $13^{\text {th }}-15^{\text {th }}$ & Roqué et al. 2007 [48] \\
\hline & & Smith et al. 2003 [54] \\
\hline & & Padeletti et al. 2003 [60] \\
\hline & & Darque-Ceretti et al. 2005 [50] \\
\hline \multirow[t]{7}{*}{ Italy } & $15^{\text {th }} / 16^{\text {th }}$ & Bontempi et al. 2006 [55] \\
\hline & & Padovani et al. 2003 [36] \\
\hline & to & Padovani et al. 2004 [56] \\
\hline & & Galli et al. 2004 [51] \\
\hline & & Padeletti et al. 2004 [38] \\
\hline & $16^{\text {th }} 17^{\text {th }}$ & Padeletti \& Fermo 2003 [52] \\
\hline & & Fermo et al., 2002 [53] \\
\hline Modern & & Roqué et al, 2006 [43,47] \\
\hline \multirow[t]{4}{*}{ Replica } & & Cepria et al. 2007 [49] \\
\hline & & Malins \& Tonge 1999 [111] \\
\hline & & Sciau et al. 2008 [98] \\
\hline & & Frederickx et al.2005 [97] \\
\hline
\end{tabular}

The polychrome lustre decor on ceramics, an innovation of the Abbasid potters [21,22,25-27,30$34]$ and thus the oldest optical device utilising nanotechnology, relies on a controlled dispersion of the metallic $\mathrm{Ag}^{\circ}$ and/or $\mathrm{Cu}^{\circ}$ nanoparticles (Table 3) within the upper region of the glaze [21,22,3560]. Layers are formed from the colloidal $\mathrm{Ag}^{\circ} / \mathrm{Cu}^{\circ}$ nanocrystals in the near-surface region (Fig. 3) of a tin (or similar multivalent metal)-containing lead silicate glaze, giving rise to an iridescent multicoloured reflective decoration. Recent studies have demonstrated that the presence of $\mathrm{Ag}^{0}$ and $\mathrm{Cu}^{0}$ nanoparticle "arrays" is responsible for this phenomenon. Table 1 summarizes the main places of production of studied lustre pottery. But the same studies have also exposed the complexities, with a large part of $\mathrm{Cu}$ and $\mathrm{Ag}$ atoms being oxidised and with a stacking of many metallic nanocrystal-containing layers acting as selective filters separated by a metal particle-free layer [21,22]. Such complex layering has also been observed in some butterfly wings (for instance Uraniidae) and beetles, in which a range of coloured scales/layers, with varying sizes and spacing, contributes to the variety of colours and iridescence ([21,22,61-64] and refs herein). Tailoring the sequence of more or less adsorbing/reflecting layers, i.e. the electromagnetic impedance of its layers is mandatory to control the light penetration from microwave to visible range $[21,22,65-70]$ as attempted for modern optical or microwave devices [67,68,70-75].

\section{Cassius purple and ruby glass}

Cassius Purple, a dispersion of gold particles in glass is named after Andreas Cassius, who described it in his treatise De auro (1685). It was also known before this date as it was already mentioned by Johann Glauber and Andreas Libavius a few decades before and the process is well described in a fourteenth-century Bolognese manuscript of painters' recipes [76,77]. This was not the only recipe to obtain red colours from gold; eighteenth-century versions of Antonio Neri's Arte 


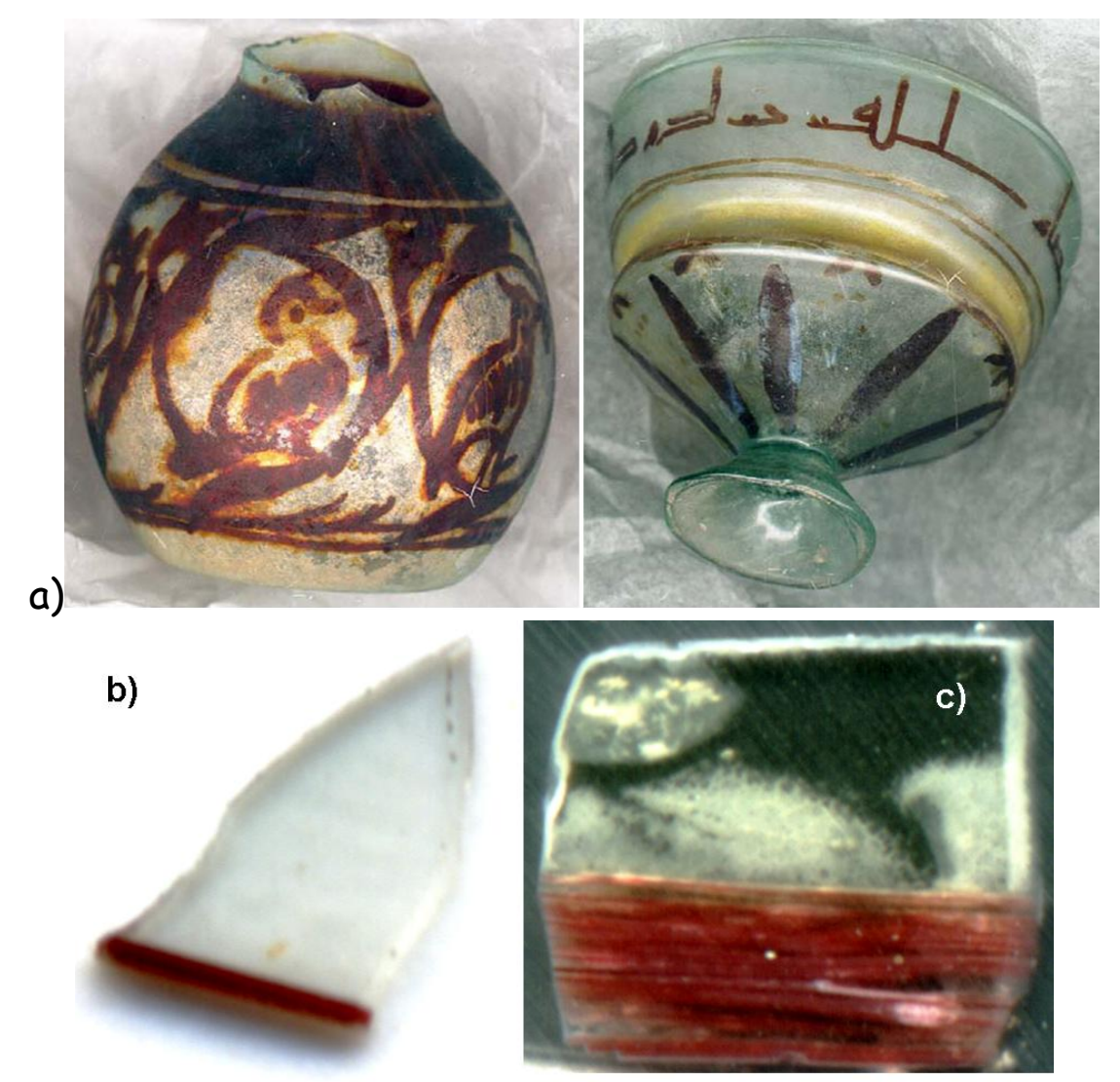

Fig. 2: Examples of lustre Fatimid glasses (a, original bottle; b, a fake [114]) and of red copper Krich glasses $(b, c)$. The samples are from b) Aube French Country $\left(13^{\text {th }}\right.$ century) and c) from Amiens Cathedral (13 ${ }^{\text {th }}$ to $17^{\text {th }}$ century), respectively [100]. (Photograph Ph. Colomban).

Table 2: Different "Lustre" synthesis according to Bertran [7].

\begin{tabular}{lllll}
\hline $\begin{array}{l}\text { Meta } \\
l\end{array}$ & $\begin{array}{l}\text { Redox } \\
\text { element }\end{array}$ & $\begin{array}{l}\text { Flux } \\
\text { element }\end{array}$ & Atmosphere & Label \\
\hline $\mathrm{Au}$ & $\mathrm{Sb} \mathrm{\&} \mathrm{Bi}$ & $\mathrm{Pb} \mathrm{\&} \mathrm{Bi}$ & - & Meissen Lustre \\
$\mathrm{Au}$ & $\mathrm{Sn}$ & $\mathrm{K}$ & - & Burgos Lustre \\
$\mathrm{Ag}$ & - & $\mathrm{Pb}$ & reducing & Yellow Lustre \\
$\mathrm{Pt}$ & - & - & - & Lüdersdorff ' Lustre \\
$\mathrm{Cu}$ & $\mathrm{Sn}$ & $\mathrm{Pb}$ & $\mathrm{H}_{2} / \mathrm{CO}$ & Lustre \\
$\mathrm{Cu}$ & & $\mathrm{Ca}$ & Reducing, & not Lustre \\
& & & water & \\
\hline
\end{tabular}

vetraria describe heating a gold powder until it turned purple and using this to create red-coloured glass [77]. The first preparation of ruby glass, is assigned to Bernard Perrot an Italian glassmaker working in Orléans ([114] and references herein). Usually, gold nanoparticles are precipitated due to tin oxide from a gold solution in regal acid and then incorporated into the glaze precursor before firing [7]. The observation of both copper and gold in red Roman glass tessarae [8] and in the Lycurgus cup [6], however questions the above proposed date for "Cassius' purple" and the gold ruby glass could be a Roman Heritage.

\section{Ancient recipes and treatises, from Middle-Ages to $19^{\text {th }}$ century and present times}

Interest in lustre techniques is however very ancient [7]. Recipes are reported in some of the oldest known technological books [76-81, and references herein]. Understanding of the ancient recipes is not straightforward and a cause of debate. With the development of a scientific approach to ceramic 
technology during the $18^{\text {th }}$ and $19^{\text {th }}$ centuries many research studies were conducted to understand and recreate the techniques, in particular at the end of the $19^{\text {th }}$ century by Théodore Deck (1823$1891)$ at the Sèvres Factory [22,82] and were even a subject of teaching [7,11,12,83]. The copies of the lustre Alhambra vase depicting a gazelle couple, made by Th. Deck, are famous (three are conserved at the Sèvres National Ceramic Museum, the Rouen Ceramic Museum and the Musée des Arts Décoratifs of Paris). In Spain the tradition has continued up to now [84]. Contemporary glassmakers and potters still employ more complex colloidal metallic dispersions of gold, silver, platinum and copper to generate desired colours in decorative glasses and enamels [22] but also try to retrieve all the parameters necessary to recreate the ancient recipes, see further.

Table 3: Composition of the lustre precursor according to Deck [82].

\begin{tabular}{|c|c|c|c|c|c|c|c|}
\hline Gold shine \#1 & $\begin{array}{l}\text { Weight } \\
\text { ratio }\end{array}$ & Gold shine \#2 & $W r$ & Red shine \#1 & $W r$ & Red shine \#2 & $W r$ \\
\hline $\mathrm{CuS}$ & 10 & $\mathrm{CuS}$ & 5 & $\mathrm{CuS}$ & 5 & $\mathrm{CuO}$ & 8 \\
\hline $\mathrm{FeS}$ & 5 & Colcotar & 1 & $\mathrm{SnO}$ & 2 & $\begin{array}{c}\text { Colcotar } \\
\mathrm{Fe}_{2} \mathrm{O}_{3}\end{array}$ & $\begin{array}{l}6 \\
5\end{array}$ \\
\hline $\mathrm{Ag}_{2} \mathrm{~S}$ & 1 & $\begin{array}{c}\text { Armenian Bole } \\
\mathrm{AgNO}_{3}\end{array}$ & $\begin{array}{l}2 \\
4\end{array}$ & & & Armenian Bole & 6 \\
\hline $\begin{array}{c}\text { Red \& yellow } \\
\text { ochre }\end{array}$ & 12 & & & $\begin{array}{c}\text { Red \& yellow } \\
\text { ochre } \\
\text { Smoke black }\end{array}$ & $\begin{array}{l}4 \\
1\end{array}$ & & \\
\hline
\end{tabular}

Colcothar consists in a intimate mixture of different iron oxides. Raw materials are ground together with vinegar and applied as thick mixture on the already glazed pottery in the desired place. After firing, the black formed coating is removed with a textile and the lustre is revealed.

As mentioned above, the earliest lustre pottery ever found was made in Iraq during the Abbasid Dynasty $\left(9^{\text {th }}\right.$ century) $[22,27,30-34,44]$. Some scholars claim that a similar lustre also exists on glass vessels from the same period or slightly before [25-26] but artefacts are very rare and poorly documented. There is only one short scientific report on lustre glass composition of pieces excavated from Fustat, the ancient Fatimid's capital that has been published, to our knowledge [85]. The first lustre glass with a reliable inscription, now at the Islamic Art Museum, Cairo, was dedicated to an official person in charge during the sole year $773 \mathrm{AD}$ [25-27], which is 20 to 50 years before the first (dated) lustre Abbasid pottery. These are the first examples of controlled nanotechnology for optical devices. It is thought that the beautiful gold-like iridescence was used to circumvent the prohibition by Islamic rule of making profane utensils of gold.

Some rare Abbasid lustre ceramics have a complex and fine decoration, the so-called polychrome lustre in which multi-coloured iridescence can be voluntarily present in the same artefact: samples have been excavated from Suze, Samara and from other Abbasid palaces, but the most known example is the Abbasid tiles, imported from Iraq, and placed in the mihrab of the Sidi Oqba Mosque in Kairuan (Tunisia) [22,30,57,58,69]. The Islamic production technology spread to Egypt, Persia, Muslim Iberian Peninsula (al-Andalus) during medieval times $\left(>12^{\text {th }}\right)$, following the expansion of the Islamic Kingdoms, and then to Italy $\left(>15^{\text {th }}\right)$ [22]. But the polychrome lustre technology (the depicted iridescent decor shine exhibits at least two colours for the same examination angle of the artefact) was lost less than a half century after its discovery. It can be seen as the work of a unique master Potter!

The French potter Théodore Deck, who produced many different types of pottery replica [82], tried to recreate a polychrome lustre in $\sim 1885$. The basic constituents were $\mathrm{Ag}_{2} \mathrm{~S}, \mathrm{CuS}$ (plus $\mathrm{HgS}$ and Bismuth for some Spanish/Italian productions) [38,47,86]. Recent studies (Table 1) mainly on Hispano-Moresque and Italian productions, more rarely on Iranian, Fatimid and Abbasid ones and on $\mathrm{Cu}^{\circ}$ or $\mathrm{Ag}^{\circ}$-containing stained glasses using UV-visible absorption [42], Transmission Electron Microscopy (TEM) [21,35,39,42,44,45,46,65], EXAFS (Extended X-ray absorption fine structure), 
SAXS and Rutherford backscattering spectrometry $[30,87,53,54]$ clearly evidence the heterogeneity of the lustre film: the lustre can be described as a $0.2-0.5 \mu \mathrm{m}$ thick layered film that contains metallic (spherical or not) nanocrystals of $\mathrm{Ag}$ or $\mathrm{Cu}$ (except in rare cases where doubts are possible, no alloying is observed) dispersed in a silica-rich glass (Table 4) and a glassy (alumina-enriched, lead-poor) metal-free outermost layer. Optical microscopy with convenient high magnification and lighting is however sufficient to detect the metal particle containing (multi) layers [21,37]. EXAFS confirms that a large part of the $\mathrm{Cu}$ content is present in the ionic form $\left(\mathrm{Cu}^{+}\right.$and $\left.\mathrm{Cu}^{2+}\right)$, as in glass [13], and not only as $\mathrm{Cu}^{\circ}$ metal [87]. Similar conclusions were drawn from Raman scattering both for $\mathrm{Cu}$ and $\mathrm{Ag}$ elements in lustre pottery [37] and red [13] or yellow glass [28]. The roughness of the lustre surface was evidenced by AFM [41] or by confocal optical measurements [22]. Obviously, the optical properties are dependent on the particle composition (Table 5), size and distribution. Lustre is indeed the first controlled nanostructured grating that was made by technicians. In the past few years, a great deal of interest has been shown in the preparation of similar nanoscale metal clusters embedded in a dielectric (e.g. glass) matrix, which are potential materials for filters or active optical devices or microwave absorbing materials [66-68,70-75].

Analyses reported above are destructive and now not allowed on rare ancient (polychrome) lustre potteries. Even optical microscopy to be efficient requires a fresh sample fracture, and in many cases appropriate polishing is mandatory. They have been performed on "recent" productions in the form of small shards or on $2^{\text {nd }}$ quality samples. We recently demonstrated the potential of Raman (micro-) spectrometry for the non-destructive classification of very different ceramics and glasses [8,88-90] as well as for a better understanding of the technology used to manufacture ancient objects [91-93]. Portable Raman instruments make it possible to study artefacts in secure places (Museum, Auction Gallery, etc.)[92]. PIXE and associated RBS techniques also provides reliable information on the sample composition. In particular composition profiles from the surface toward the core are very useful to discriminate between $\mathrm{Au}, \mathrm{Cu}$ and $\mathrm{Ag}$-enriched regions [93-95]. If usual instruments require small samples, big instruments like AGLAE at C2RMF [93-95] offer the unique possibility to study big objects. Alternatively the use of portable LIBS and XRF spectrometers is a convenient way to analyse big, non-moving artefacts. In particular LIBS instrument allows the quantitative study of the glaze layers [59].

Another approach has become popular, namely the study of modern replicas, prepared at the laboratory [42,43,47,49,96,97] or better by modern potters using gas firing [98]. This point will be discussed further.

The old potter reports, such as that written by Abû al-Qâsam [78], a member of an Iranian potter family, explain that the lustre is obtained by putting a mixture of clays and ochres, silver and copper salts (sulphides, sulphates, other salts...), vinegar and dregs in specific places for decoration control of an already silicate glazed piece of pottery [22,78-81]. Deck' recipes are given in Table 3 [82]. The whole system is then heated in a dark red $\left(\sim 600-700^{\circ} \mathrm{C}\right)$ kiln in a mostly reducing atmosphere (oxidizing conditions at the cycle end are sometimes noted and it is clear that temperature/atmosphere control is complex [21,22]). Usually the glaze contains some lead (Table 4) but rare lead-free glazes are also reported [27,43,44]. For a silver-based yellow stained glass the technique is very similar [7,11,12,28]. For a red copper stained glass the technique must be different [97] because of the very strong absorption of $\mathrm{Cu}^{\circ}$ containing glasses which requires a very thin metal-containing layer (Figs $2 \mathrm{bc} \& 3 \mathrm{ef}$ ). Furthermore, strong mechanical requirements requested for stained glass necessitate the glass piece to be quite thick $(2-10 \mathrm{~mm})$. Usually a multilayer glass coating is obtained by flashing a glass bubble: the glass bubble is blown to a very thin thickness (tenths of microns) and splashed over a glass plate to cover it. This technique is still used in some Venetian workshops for the preparation of gilded tesserae, where a very thin gold sheet $(10-20 \mu \mathrm{m})$ is sandwiched between a thick support and the flashed glass coating, the Cartelina [93]. This technique was also used in the 1970's to fill the gap between the two magnetic parts of the first produced video recorder heads. Another potential technique is the dipping of the glass batch extracted from the melt with the tube, alternatively in copper-containing and copper-free molten glass. The blowing makes thinner the glass layers. 

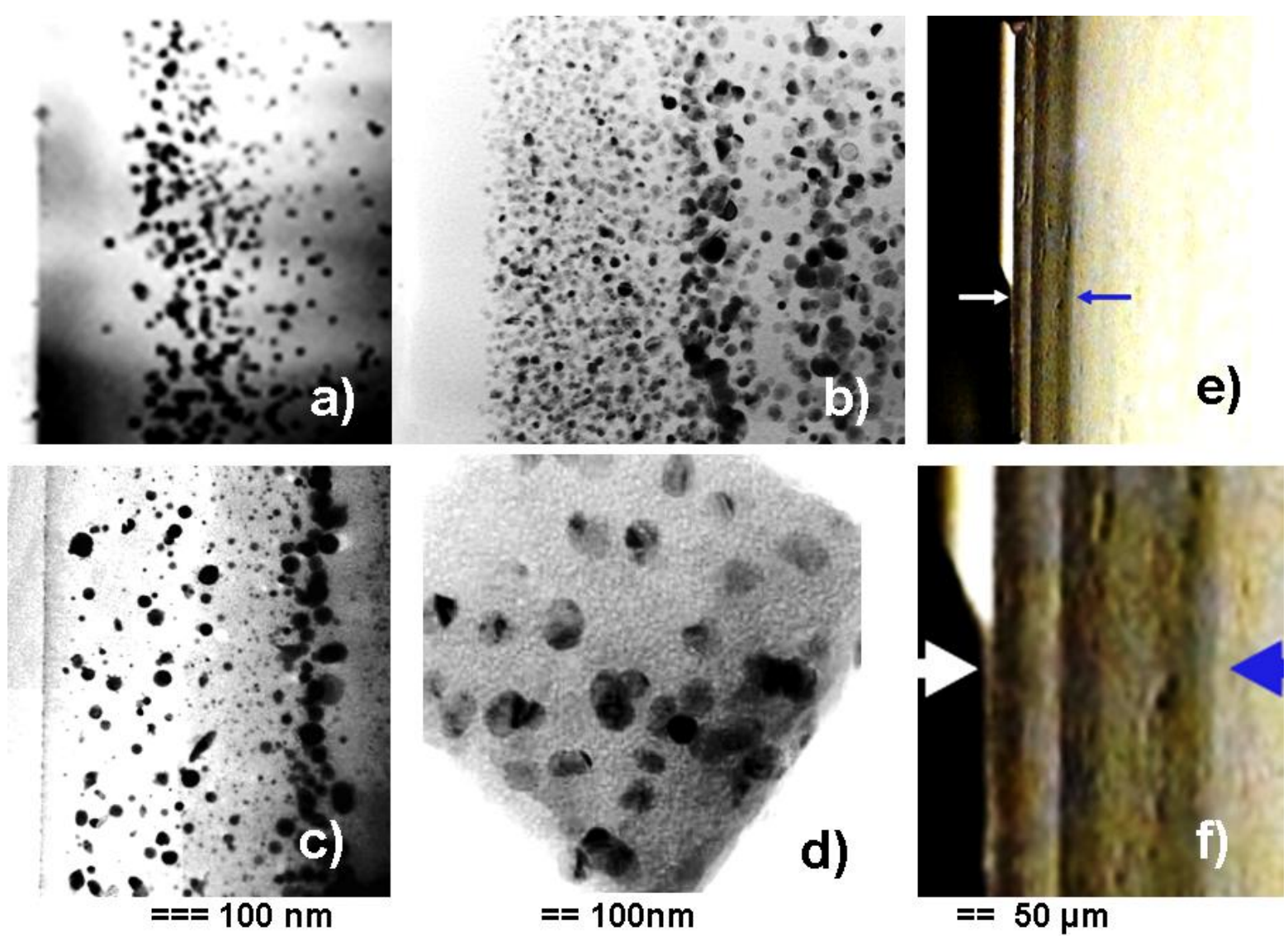

Fig. 3 : Examples of Transmission Electronic Microscope images obtained for sections perpendicular to the glaze surface of a) a Mesopotamian lustre (Abbasid, $9^{\text {th }}$ century, courtesy of $\mathrm{Ph}$. Sciau, see similar analysis in [45]), b) Fustat Fatimid red lustre (see details in [22]), c) Eva Haudum' gold-like replica [98] and d) a modern materials developed for microwave adsorption [70]; e) optical micrograph of the section of a red flashed glass on its colourless support, f) detail of the red film; note the 3 layers with $\mathrm{Cu}^{\circ}$ and the interlayers free of metal precipitate.

\section{Micro and nanostructures}

After the description of the main recipes in order to specify the stringent phenomena we will discuss their effects on the colour shine, the importance of the host glass/glaze matrix composition and nanostructure, the mechanisms of metal particle reduction by the combined action of furnace atmosphere and redox equilibrium, and we will try to classify the different microstructures. Finally we will consider the non-destructive Raman analysis of different glasses and glazes and the possible differentiation between genuine artefacts and fakes.

The experimental evidences are summarized in Figs $3 \& 4$ : i) the dispersion of $\mathrm{Ag}^{\circ}$ and $\mathrm{Cu}^{\circ}$ nano precipitates in the glaze near its surface in a complex distribution which in many cases does not fit with the gradient expected for a steady temperature behaviour with a source of $\mathrm{Ag}$ or $\mathrm{Cu}$ at the sample surface, ii) the metal particle free surface layer is observed in most of the TEM studied lustres, iii) the higher refractivity of the uppermost surface film (less PbO) (e.g. in [35]), iv) a rather large distribution of the particle size, from 1 to $100 \mathrm{~nm}$. The metal content ranges between 0.1 and 2 wt\%. According to Deck's formula and corresponding Surface Plasmon Resonance peak (Table 5) the red colour (not shine) results from copper and the gold one from silver. Actually, this is more complex. We will see further that these colours are directly related to the wavelength of the plasmon resonance peak (Table 5) and it is important to say that the plasmon peak wavelength and shape depend on many parameters: particle size, inter-particle distances and electronic coupling, etc. $[68,75,96]$. This colour is different in its nature than the colour of the lustre iridescence. 
1

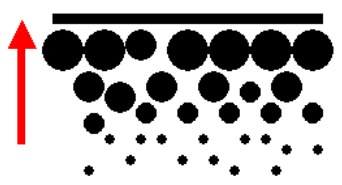

3

2

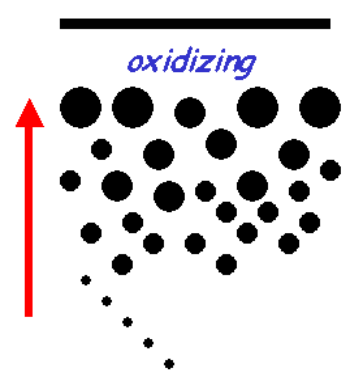

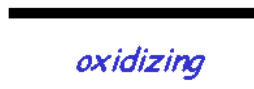
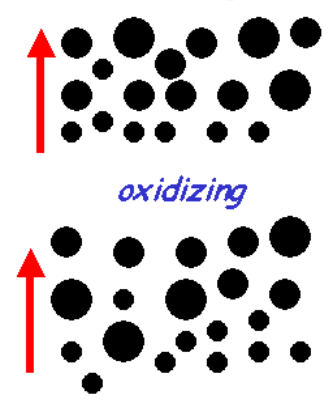

4

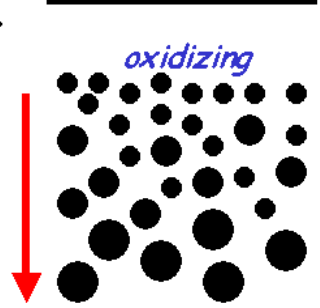

Temperature

Gradient

Fig. 4: Schematic of the different types of the lustre microstructure associating zones with or without metal nanoprecipitates and with different orientation of the size gradient. Thick solid line: glass surface.

Fig. 3 compares representative TEM images and the different microstructures are schematised in Fig. 4. Nice TEM images are difficult to obtain because of the poor mechanics of many glazes; a new FIB device is very useful [21] for the in situ thinning of the lustre glaze. Four microstructures are observed: the metal nanoparticles close to the surface (Type 1) with or without a metal-free upper layer (Type 2), multilayer sequence (Type 3) and the sequence with inverted gradient size (Type 4). All these microstructures have been observed in the literature, and the best sheen is observed for the multilayer structures, as for opals [1,24] and beetles $[21,63]$. By comparison with the modern tailored nanocomposites for microwave penetration control or optical devices [7075,99], it has been pointed out that the metal-free upper layer acts as adapted impedance layer to avoid reflection at the air/glaze interface and the successive bilayers (metal-containing, metal-free) improve the wavelength selectivity (i.e. in visible range for colour) [20,21], in other words a better diffraction of the light. It is obvious that the Type 1 microstructure does not differ from gilding, a coating with flux addition and that the so-called Meissen Gold Lustre belongs to this type (Table 2).

A great effort has been made in the last few years to understand the different steps involved in lustre production by means of replica preparation [42,43,47,49,96-98] and the comparison of the achieved microstructures with those of artefacts produced at different periods in various workshops. However, it is obvious that modern techniques of firing are different from the older ones, especially regarding the heating fuel and duration of thermal cycles. In the past - and this was true up to the first part of the $20^{\text {th }}$ century in many countries - the duration of a firing cycle exceeded days and sometimes weeks (e.g. in Chinese Dragon kilns). Thus lower temperatures than those used by modern potters are convenient and made it possible to control the size of bubbles, precipitates, reactions in the glaze or at the glaze-body interface more precisely [19].

\section{Colour by absorption (SPR) and by diffraction (lustre shine)}

Colours. The absorption of silver, gold and copper particles in the visible range gives rise to a narrow peak, the so-called Surface Plasmon (electron) Resonance or SPR, a collective oscillation of the free electrons at the surface of metal nanoparticles, at respectively 400, 520 and $570 \mathrm{~nm}$ (Table 5 \& Fig. 5) [5, 66,96,99,100,101]. The shape and exact position depend on several parameters such as the nature of the metal, the dimensions of the particles, their volume fraction and the nature of the glassy host matrix. An example is given for copper red stained glass in Fig. 5. A very thin layer of metal-containing glass is sufficient to absorb strongly at wavelengths below SPR and a continuous metal layer is almost transparent for wavelengths above SPR. Thus, in order to prevent 
the stained glass from becoming opaque, middle-aged flashed glass are constituted of stacks of thin films, alternatively clear or containing $\mathrm{Cu}^{\circ}$ particles, with thicknesses of $\sim 20$ to $100 \mu \mathrm{m}$, coated on an optically clear glass plate (Fig. 2). Due to the preparation process of glass bubbling, the glass plates have a characteristic corrugated surface [100], which can be used by scholars to identify such glasses by touching with their fingers, eyes being closed for a better sensitivity! Usually the $19^{\text {th }}$ and $20^{\text {th }}$ century red glasses consist of a single thin film on the colourless support with a flat surface. In the later case, acid (HF) etching was used to mimic the colour heterogeneity of red middle-aged flashed glasses.

Table 4: Typical lustre glaze compositions after [27,31,37,44,95].

\begin{tabular}{|c|c|c|c|c|c|c|c|c|c|c|c|}
\hline $\begin{array}{c}\text { Oxide } \\
\% w t\end{array}$ & $\mathrm{SiO}_{2}$ & $\mathrm{PbO}$ & $\mathrm{SnO}_{2}$ & $\mathrm{Na}_{2} \mathrm{O}$ & $\mathrm{K}_{2} \mathrm{O}$ & $\mathrm{Al}_{2} \mathrm{O}_{3}$ & $\mathrm{CaO}$ & $\mathrm{FeO}$ & Dynasty & century & Body \\
\hline Glaze & $\begin{array}{l}40- \\
75\end{array}$ & $5-40$ & $5-15$ & $0.1-3$ & $2-9$ & $2-5$ & $1-15$ & $0.2-2.5$ & & & $\mathrm{~A}, \mathrm{~S}$ \\
\hline $\begin{array}{l}\text { Meso- } \\
\text { potamia }\end{array}$ & $\begin{array}{l}70- \\
75\end{array}$ & $0-8$ & $0-10$ & $<5$ & $<5$ & $<2$ & 5 & $<4$ & Abbasid & $9^{\text {th }}-10^{\text {th }}$ & A \\
\hline Egypt & 45 & $25-30$ & $15-20$ & $<4$ & $<4$ & & & & Fatimids & $\begin{array}{l}10^{\text {th }}-12^{\text {th }} \\
12^{\text {th }}-13^{\text {th }}\end{array}$ & $\begin{array}{l}\text { A } \\
A, S\end{array}$ \\
\hline Syria & 75 & 0 & 0 & $\sim 5$ & $\sim 5$ & & $5-7$ & & $\begin{array}{l}\text { Ayyubids } \\
\text { Mameluk }\end{array}$ & $12^{\text {th }}-15^{\text {th }}$ & S \\
\hline Iran & $\begin{array}{l}50- \\
65\end{array}$ & $15-20$ & $5-15$ & $<4$ & $<4$ & & & & Timourids & $\begin{array}{l}11^{\text {th }}-15^{\text {th }} \\
14^{\text {th }}-15^{\text {th }}\end{array}$ & $\begin{array}{l}\text { S } \\
\text { A }\end{array}$ \\
\hline $\begin{array}{l}\text { Iberian } \\
\text { Peninsula }\end{array}$ & $\begin{array}{l}45- \\
50\end{array}$ & $35-40$ & $5-20$ & $<4$ & $<4$ & & & & $\begin{array}{l}\text { Nasrids } \\
\text { Mudejar }\end{array}$ & $\begin{array}{l}13^{\text {th }} \\
<15^{\text {th }}\end{array}$ & $\begin{array}{l}\text { A } \\
\text { A }\end{array}$ \\
\hline $\begin{array}{l}\text { Upper } \\
\text { glaze }\end{array}$ & 71 & 1.5 & & 4.5 & 2.5 & 13 & $\sim 5$ & 1.7 & & & \\
\hline
\end{tabular}

Body: A : clay-based paste; $\mathrm{S}$ : highly siliceous body

Metal particle size determines the position and shape of the SPR peak in a complex fashion. Furthermore the chemistry of silver is also complex. As for thallium, the lone electron pair promotes bonding between neighbouring cations and $\left(\mathrm{Ag}_{\mathrm{n}}\right)^{\mathrm{m}+}$ clusters, with $\mathrm{m}<\mathrm{n}$, can be formed $[102,103]$, modifying the electronic absorption.

Table 5: Plasmon adsorption for gold, copper and silver particles.

\begin{tabular}{l|ll}
\hline $\begin{array}{l}\text { Meta } \\
l\end{array}$ & $\lambda$ Plasmon & References \\
\hline $\mathrm{Au}$ & $500-550 \mathrm{~nm}$ & [99] Qu et al. \\
$\mathrm{Ag}$ & $\sim 400 \mathrm{~nm}$ & [101] Bakumov et al. \\
\hline $\mathrm{Cu}$ & $565-570 \mathrm{~nm}$ & [96] Schreiber et al. \\
\hline
\end{tabular}

The present knowledge on metal nanocomposites questions the former assignment of the red colour of the Lycurgus' cup to gold and silver particles [6]. However the gold content is very low. A large amount of copper was measured but assigned to the copper grill. It is likely that a part of the copper content was really within the glass and contributes to the dichroic effect. As described above, the colour of the lustre sheen is not directly related to the SPR but to the more or less gold diffraction of the light by the gratings formed by the metal particle-containing layers. This phenomenon can be described by Mie scattering [69] but actually consists in the well-known Bragg scattering by a poorly ordered structure [22-24]. 


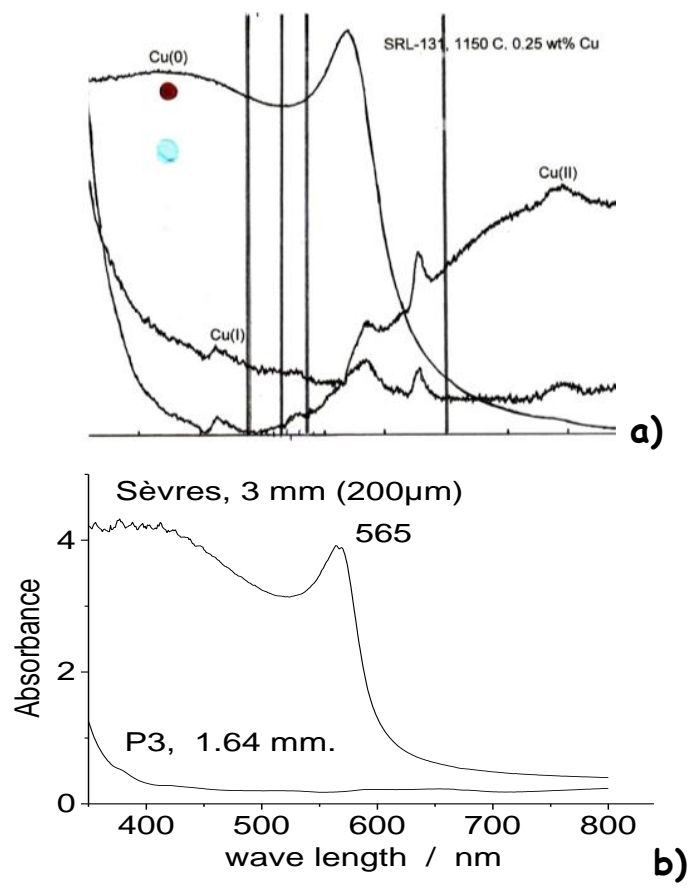

Fig. 5: a) UV-visible absorption spectrum recorded for the Eu-doped model glass with $0.25 \mathrm{wt} \%$ of copper; copper is present as $\mathrm{Cu}^{\circ}$ nanoprecipitates (upper curve with the SPR peak) or as $\mathrm{Cu}^{+}$(colourless) and $\mathrm{Cu}^{2+}$ ions (absorption above $600 \mathrm{~nm}$, reproduced from $\mathrm{J}$. Raman Spectroscopy 36 (2005) 884, (C) Wiley, with permission [96]); lines correspond to blue, yellow, green and red laser wavelengths; b) UV-visible spectra recorded on red copper glass $\left(19^{\text {th }}\right.$ century Sèvres workshop) and on the corresponding colourless homologue (P3). The sample and the red film thicknesses are given.

\section{The solid state chemistry}

Glass and glaze host matrix composition. As a function of the raw materials used, three main compositions are observed for glasses prepared before the $19^{\text {th }}$ century and the Leblanc route of synthetic soda: i) Na-rich, (12-18 wt \%) low Mg ( $<0.8 \mathrm{wt} \%)$-content glasses prepared with natron from the Middle-East as soda source, ii) $\mathrm{Na}-\mathrm{Ca}$ (5-10 wt\%)-rich high $\mathrm{MgO}$ (3-6 wt\%)-content glasses prepared from desert plant ash and iii) K-Ca-rich Middle Aged glasses prepared with forest plant ashes [89-91,100,104-106]. Because of recycling of glass since Roman times, intermediate compositions are also observed. The composition of the analysed medieval flashed red glass of Fig. 5 belongs to the last group, i.e. a K- and Ca-rich composition [28,29,91]. On the other hand, most of the studied $19^{\text {th }}$ century red glasses are Na-rich compositions $[97,100]$.

The series of recent analyses discussed above make it possible to give representative composition ranges of lustre glazes (Table 4). Note the large dispersion observed for lead content. In fact, as far as the glaze compositions are concerned, three main types are encountered. In some cases the composition is very close to that of Punic/Roman glass, with some addition of lead, as observed for red glass tesserae. Two other groups are recognized, the rare lead-free compositions, with $\mathrm{Na}_{2} \mathrm{O}$ and $\mathrm{K}_{2} \mathrm{O}$ ranging from 4 to $10 \mathrm{wt} \%$ and the mixed compositions where $\mathrm{PbO}$ content varies between 5 and $30 \mathrm{wt} \%$, rarely $40 \mathrm{wt} \%$ [27,31,37,44]. Fustat Fatimid's samples have a medium $\mathrm{PbO}$ content [37]. The lead content is very low, some time nil in some Abbasid pottery glaze [37]. Tin oxide content close to $7-10 \mathrm{wt} \%$ corresponds to the threshold level for precipitation when the molten glaze is cooled down. On the contrary, huge $20 \mathrm{wt} \%$ content arises from the deposit of a tin-rich slip before the glaze. When analysed, the upper metal-free layer seems to have a much lower lead content [35], which is consistent with firing in a strong temperature gradient. 
Reducing into metal particles: Redox short-circuit and firing atmosphere. The network of a glassy silicate is built of strong covalent $\mathrm{Si}-\mathrm{O}$ bonds. Consequently the melting temperature of silica is high and the diffusion coefficients of oxygen and silicon atoms in silica are very low, even in the molten state. Fast oxygen molecule diffusion requires high temperature. Thus, the action of the kiln atmosphere on oxidation/reduction in a glass or a glaze requires some short-circuits to be efficient $[21,22,66,107-111]$.

Two routes can be used:

- i) the presence of multivalent elements such as $\mathrm{Sb}, \mathrm{Sn}, \mathrm{Bi}, \mathrm{Fe}$ which diffuse fast in the silicate network and can promote the reduction of copper or silver ions, after having themselves been reduced at the surface where they are in contact with a reducing atmosphere; for instance we have a reduction of the following elements

$$
\begin{aligned}
& \mathrm{Sb}^{5+}+2 \mathrm{e}=>\mathrm{Sb}^{3+}(1) \\
& \mathrm{Sn}^{2+}+\mathrm{e}=>\mathrm{Sn}^{+} \\
& \mathrm{Bi}^{5+}+2 \mathrm{e}=>\mathrm{Bi}^{3+} \\
& \mathrm{Fe}^{3+}+\mathrm{e}=>\mathrm{Fe}^{2+}
\end{aligned}
$$

and then in the glaze, for instance

$$
\begin{aligned}
& \mathrm{Sb}^{3+}+2 \mathrm{Ag}^{+}=>\mathrm{Sb}^{5+}+\left[\mathrm{Ag}^{\circ}\right]_{2} \\
& 2 \mathrm{Sn}^{+}+\mathrm{Cu}^{2+}=>2 \mathrm{Sn}^{2+}+\mathrm{Cu}^{\circ}(6) \\
& \mathrm{Bi}^{3+}+2 \mathrm{Ag}^{+}=>\mathrm{Bi}^{5+}+\left[\mathrm{Ag}^{\circ}\right]_{2}(7) \\
& 2 \mathrm{Fe}^{2+}+\mathrm{Cu}^{2+}=>2 \mathrm{Fe}^{3+}+\mathrm{Cu}^{\circ}(8)
\end{aligned}
$$

Modern techniques use Europium ions to trigger the reduction of copper ions for the preparation of dichroic glass [66,106-109]

- ii) the diffusion of hydrogen within the glassy silicate [70,71,111]. The very small size of the hydrogen molecule allows a fast diffusion which can reduce ions directly, without the help of the above redox equilibria:

$$
\mathrm{H}_{2}+\mathrm{Cu}^{2+} \Rightarrow \mathrm{Cu}^{\circ}+2 \mathrm{H}^{+}(9) \text {. }
$$

Actually, the control of the kiln atmosphere cannot be independent of the temperature control. For instance, hydrogen is a very good fuel and its injection increases the temperature. Hydrogen is produced by the reaction of water with $\mathrm{CO}$ or (wood) coal but, on the other hand water excess, often associated with hydrogen production from green wood, will decrease the temperature. Ancient potters used green wood faggots to produce hydrogen in the kiln atmosphere but this also produces a large amount of water vapour, which makes it rather difficult to keep the temperature under control. The roles of hydrogen and water were extensively discussed by Malins \& Tonge [111]. Fig. 3 shows a TEM image [98] obtained for a modern lustre, made in 2008 by Eva Haudum, a potter working in France [112]: Two metal-rich layers are observed which corresponds to the Group 3 multilayer lustre classification. This lustre has been obtained by 4 sequences of reduction (by $\mathrm{CO}$ ) at $580^{\circ} \mathrm{C}$ followed by an oxidation, which leads to an increase of the temperature by about $100^{\circ} \mathrm{C}$. The upper layer(s) free of metallic particles were obtained under oxidizing conditions. The need of reducing/oxidizing sequences as proposed before [21,22] is clearly demonstrated. 
Obviously, for Type 1 microstructure where metal particles are very close to the glaze surface, redox go-between elements are not required and reduction/oxidation can be monitored by the kiln atmosphere.

Metal particles, their distribution and their preparation. In a previous report [22] we proposed a description of the polychrome lustre formation according to the Abû al-Qâsem recipe, a mixture of dregs, vinegar, ochre, clays and silver/copper salts. This assumption was confirmed by some TEM measurements [21], which clearly demonstrate that the local surface temperature reaches temperatures much higher than expected from the kiln temperature mentioned in ancient recipes. This demonstrates that lustre cannot be obtained in constant temperature and atmosphere. Ancient al-Qâsam recipes indicate that the addition of wood to obtain smoke should be carefully controlled. The technique is called 2-fire colour. An explanation has been proposed [21,22]: combustion of organic residues from the lustre precursor paste at the sample surface gives incandescence which is well visible for samples in a dark red kiln $\left(\sim 600^{\circ} \mathrm{C}\right)$. This offers a control of the surface temperature in different places of an artefact, as required to control a complex colour design through that of the metal particle size and size gradient. An alternative route is a flash heating by entering the sample in the fire during a limited time in order to heat only the sample surface. This technique was used by Islamic and Roman glassmakers, as demonstrated by their use of enamelled glass with a composition very similar to that of the body ([113,114] and references herein).

Lead oxide is easily dissolved at $80-100^{\circ} \mathrm{C}$ by the acetic acid from the vinegar and dregs mixture and therefore the roles of these reagents added to the clay/ochre are clear. Namely, they increase the porosity of the top surface of the glaze to maximize the reaction with the molten $\mathrm{Ag}$ - or $\mathrm{Cu}$-rich melt. The clays-salts mixture hinders the fast evaporation of acetic acid, which improves the dissolution of the lead oxide-based glaze. The near surface region of the glaze becomes porous. Further heating causes the melting of silver and copper salts entering the meso-porosity formed by the action of the acetic acid, and their ions diffuse to some extent into the glass network. The low temperature $\left(200-400^{\circ} \mathrm{C}\right)$ ion-exchange between a solid open framework, like that of a glassy silicate, and a molten nitrate is well documented [115-117]. Metal particles form by coalescence or liquid separation between the molten glaze and the metal. This is consistent with the spherical metal particle shape [22,35] and size distribution, and is close to that observed in sol-gel prepared nanocomposites by $\mathrm{H}_{2}$ reduction [70-72]. This causes a decrease of particle concentration (gradient) from the sample surface (the source) toward the pottery body centre. Effectively such a microstructure is observed in Mesopotamian (Fig. 3), Italian and Moresque monochrome lustre as well as in some modern reconstructions. The multilayer structure of some Fustat (Fatimids, $11^{\text {th }}-12^{\text {th }}$ century) and Termez ("Iran", $13^{\text {th }}-14^{\text {th }}$ century) samples [22,35], differs from the other lustres (except for some instances, Mesopotamian /Abbasid samples from [45,118]) and may have required a more complex synthesis. Furthermore, the worm-shape of the Ag precipitates in some samples [22] proves that the melting temperature of silver $\left(\sim 960^{\circ} \mathrm{C}\right)$ was reached in some spots close to the sample surface. The observation of facetted crystals also proves that a temperature very close to $1000^{\circ} \mathrm{C}$ was achieved at the sample surface. Diffusion controlled phenomena cannot lead to such worm-shapes or facetting. This temperature causes the complete volatilisation of $\mathrm{PbO}$ from the upper glaze as the melting temperature of $\mathrm{PbO}$ is $\sim 880^{\circ} \mathrm{C}$. This temperature corresponds to that required for modern (i.e. acetic acid free) lustre techniques [22,119].

The lead diffusion in the glaze makes that residual acetate still remains at the glaze surface. Acetates are thermally rather stable and temperatures higher than $300^{\circ} \mathrm{C}$ are required to decompose them in carbon-rich residues under a reducing atmosphere. However, if a sufficient amount of oxygen is added after formation of the carbonaceous residues i.e. above $500^{\circ} \mathrm{C}$, a glowing phenomenon can be observed similar to what is usually observed in some sol-gel synthesis routes [2,120]: acetate residues burn and the surface temperature of the ceramic can reach a temperature of $1000^{\circ} \mathrm{C}$ or more, as required to melt $\mathrm{Ag}$ and $\mathrm{Cu}$. The high crystalline quality of metal nanoprecipitates is also consistent with intense local heating [21]. Such a phenomenon could explain the special composition of the lustre surface: less $\mathrm{PbO}$ because its evaporation is very active 
above $900^{\circ} \mathrm{C}$, more $\mathrm{Al}_{2} \mathrm{O}_{3}$ because a reaction with clays, from the precursor mixture, is also possible and no metal precipitates because of surface oxidation. This also explains the decrease of the particle size from the surface to the pottery core, i.e. with the temperature gradient within a layer. The composition of the mixture (more or less vinegar and dregs, $\mathrm{Ag} / \mathrm{Cu}$ content...) will control the surface temperature as well as the embedded metal dispersion and allows one to set the final lustre colour in different places of the same item. The strong temperature gradient arising from the surface residue combustion explains why the precipitates located just below the glaze surface have a larger size and also the formation of elongated particles. The large size gradient for metal particles fit well with a flash temperature which prevents homogenisation. It is clear that wetability and metal/molten silicate surface energy also may control the particle shapes: separation of two liquid phases between the molten metal and the silicate melt is another possibility. However, this does not explain the multilayer pattern. This special pattern involves one, two or more successive deposits of the metal source mixture and/or associated repeated flash reduction/oxidation conditions. However, only the surface exothermic combustion can explain the achievement of two or more coloured types of lustre on the same artefact, as achieved by Abbasid potters [21,22,58]. This multi-step route allows the preparation of polychrome lustre glazes (i.e. different lustre colours), on the same artefact, by control of the temperature generated on different places on the pottery by the acetate residues combustion.

To summarize, the elongated shape of the bigger particles can be explained by an anisotropic flash heat. In contrast, a homogeneous temperature will give coalescence of the globular particles by Ostwald's ripening process. The production of the flash temperature can be explained by

i) the exothermic combustion of the surface organic residues; this technique allows to control, empirically, the flash temperature in different spots on the sample;

ii) by in- and out-taking of the pottery/glass in/from the kiln, as usually done by glass-makers for enamelling and also today by modern potters producing monochrome lustre pottery;

iii) by multiple modifications of both temperature and atmosphere $\left(\mathrm{H}_{2}, \mathrm{CO}, \mathrm{O}_{2}\right)$, as experimented by Eva Hundum replicas, as long as the source of metal element at the sample surface is not consumed. This technique was actually already reported in Piccolpasso's treatise [80]. He says that big broom fagots must be added ones after the other during firing. As recently explained by Allan Caiger-Smith, a modern lustre potter [121], the big size of the fagots requires the end of their burning before to add a new one, and thus an oxidizing sequence takes place between each reduced one;

iv) or by a combination of these actions. Obviously lustre pottery and glass are a craftsman's masterpiece!

\section{Non-destructive analyses}

Host matrix and the nano-particles. Among the non-destructive available methods, Raman spectroscopy is one of the most versatile techniques, especially for the analysis of glassy and nanosized materials [4,122]. Raman spectroscopy probes molecular and crystal lattice vibrations and therefore is sensitive to the composition, bonding, chemical environment, (nano)phase, and (nano)crystalline structure of the sample material [4]. First, the micronic resolution of common optic instruments is accessible because a laser is used as the excitation source. The signal intensity depends on the laser wavelength (high with violet excitation, very poor with IR) and of the coupling between the laser light and electronic levels of the analysed matter, in other words of the colour of both: thus for a lustre material strong differences are expected for laser excitation below the SPR (absorbent material) and above (transparent material, Fig. 5). Note that in the former case the Raman signal will be very weak because of the huge absorption, both of illuminating and scattered light (Fig. 7).

All applications in the science, art and technology of glass, glazes and enamel consist of a controlled modification of the three-dimensional $\mathrm{Si}-\mathrm{O}$ network by the replacement of $\mathrm{Si}^{4+}$ covalently bonded atoms by ionic bonded ones. This decreases the number of Si-O bridges and the 
connectivity of the network, i.e. modifies the glass nanostructure and associated properties such as the melting temperature, viscosity, thermal expansion.... The $\mathrm{SiO}_{4}$ tetrahedron is a strong chemical (silicate melts remain polymerised) and vibrational entity and the Raman signature reveals the different $\mathrm{SiO}_{4}$ conformations and their relationship with the signature of parent crystalline homologues: nesosilicates built of isolated $\mathrm{SiO}_{4}$ tetrahedra, soro-silicates of tetrahedras sharing a bridging oxygen ... up to tectosilicates where oxygen atoms are shared between adjacent tetrahedra [88,89 and references herein]. Consequently, the Raman spectra of glasses were decomposed following a model which considers the two main components, the Si-O bending and stretching bands at $\sim 500$ and $1000 \mathrm{~cm}^{-1}$ as multiplets enveloping curves of the series of Gaussian-shaped components associated at each type of $\mathrm{SiO}_{4}$ tetrahedron $\left(\mathrm{Q}_{\mathrm{n}}\right.$ components), linked by 0 (isolated $\mathrm{SiO}_{4}$ tetrahedron), 1 (two tetrahedral sharing one oxygen to form $\mathrm{Si}_{2} \mathrm{O}_{7}$ entity), 2, 3 or 4 common oxygen atoms. The transition from a highly connected tetrahedral structure (such as quartz and amorphous silica) to a weakly or un-connected tetrahedral units (such as $\mathrm{CaSiO}_{3}$ wollastonites or lead-based glaze) as caused by the addition of fluxing agents is reflected in the Raman spectrum by modifications of the intensity of the Si-O stretching multiplet (centre of gravity $\sim 950$ to $1150 \mathrm{~cm}^{-1}$ ) vs. the bending one (centre of gravity $\sim 500$ to $600 \mathrm{~cm}^{-1}$ ) [88]. The relationship between the Raman index of polymerisation (Ip $=\mathrm{A}_{500} / \mathrm{A}_{1000}$ with $\mathrm{A}$ being the area under the Raman band), the glass composition and the processing temperature is now well documented [28,37,88,89,92,96,123-127]. For instance this has been used to classify silver-containing yellow stained glass replicas [28] and ancient red or yellow stained glasses [96,100]: for instance a clear relationship was established between the polymerization index, the Area of $Q_{n}$ components and the $b^{*}$ colour coordinate as a function of the silver content and its degree of reduction [28].

a)

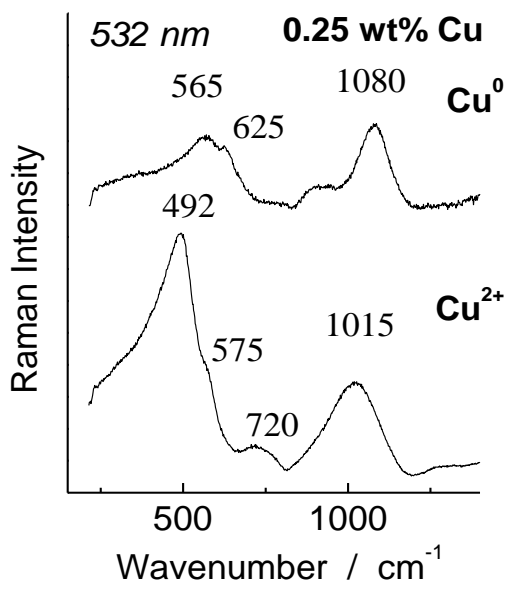

b)

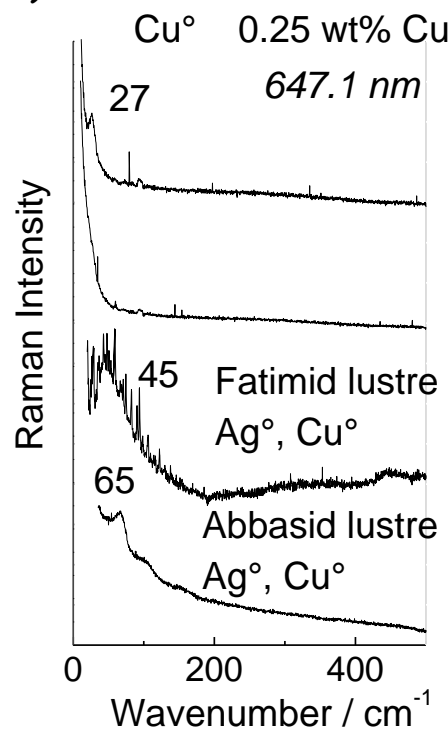

Fig. 6: a) Raman spectra recorded on the Cu-containing model Eu-doped glass with same amount of copper as $\mathrm{Cu}^{\circ}$ nanoprecipitate or $\mathrm{Cu}^{2+}$ ions (after [96]). b) Details presenting the low wavenumber region (cluster \& ion translational modes) of the model Eu-doped $\mathrm{Cu}^{\circ}$ glass and of two ancient lustre glazes, the Fustat Fatimid red palmetto shard (Fig. 1d-e) and the Suse Abbasid polychrome shard (see [37]).

We will take an example to show the potential of the technique. Fig. 6a compares the Raman signatures obtained for the same model glass (a Na-rich composition [96] where the copper reduction is controlled by Eu ions doping) with $0.25 \mathrm{Cu}$ wt $\%$ in the following different forms, $\mathrm{Cu}^{\circ}$, $\mathrm{Cu}^{+}$(not shown) and $\mathrm{Cu}^{2+}$. Differences are obvious, both on UV-visible absorption spectra (Fig. 5a) 

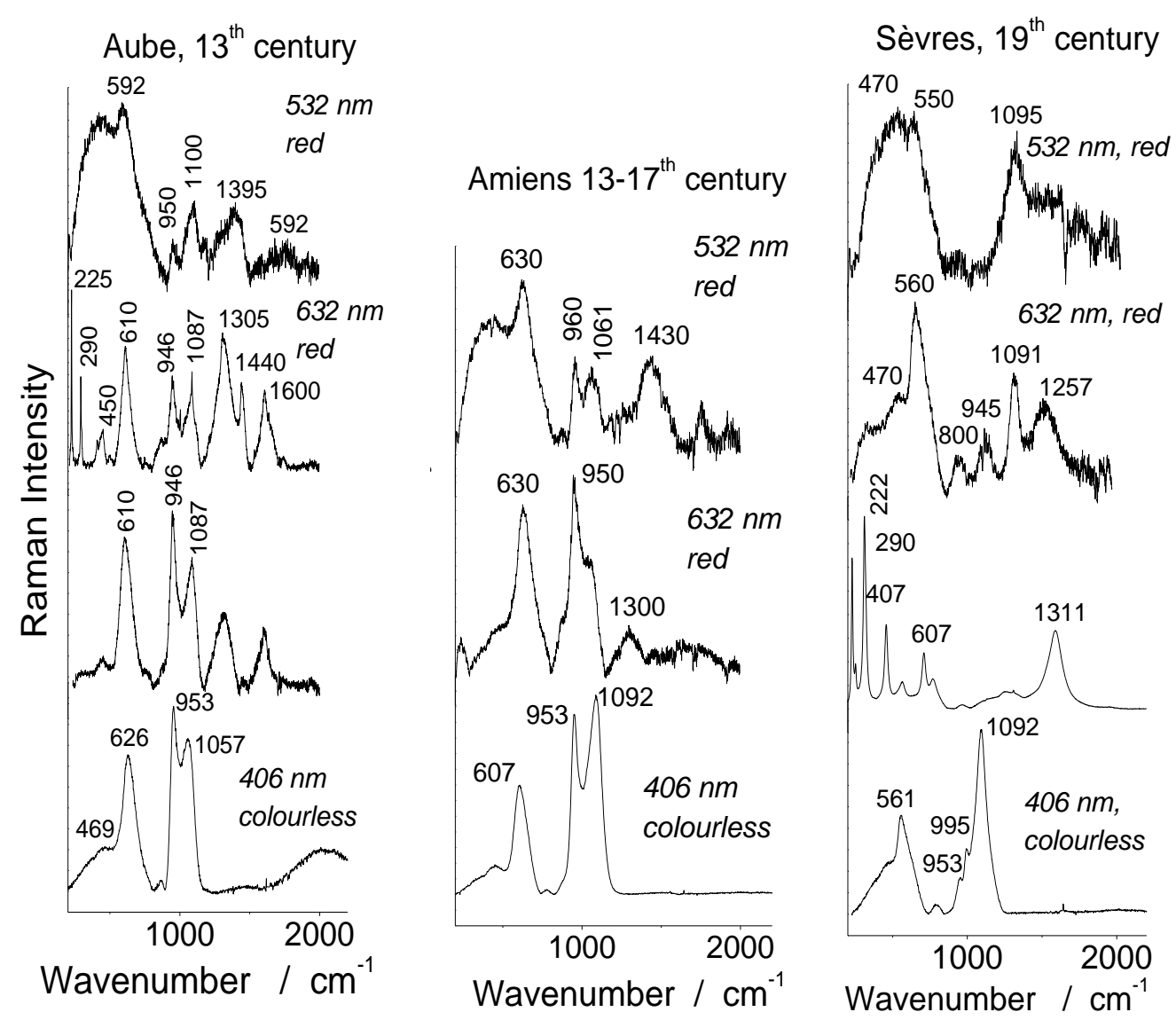

Fig. 7: Raman spectra recorded on the red flashed glasses $\left(13^{\text {th }}\right.$ to $19^{\text {th }}$ century $)$ using different laser wavelengths in the red and colourless places. A baseline has been subtracted for spectra recorded on coloured glass because the huge absorption of the light and the very poor Raman intensity.

and Raman signature: a narrow SPR is observed for $\mathrm{Cu}^{\circ}$ containing, red glass although absorption is low for light-blue $\mathrm{Cu}^{2+}$-containing glass sample and nil for $\mathrm{Cu}^{+}$-containing glass [96]. Fig. 7 compares the spectra recorded on copper red stained glasses from different origins: ancient middleage glass pieces from the Amiens Cathedral (Picardie), assigned to be made between the $13^{\text {th }}$ and the $17^{\text {th }}$ century, from a ancient church of Aube Country, close to Reims city, the place where Kings of France ware sacred and $19^{\text {th }}$ century glass produced at the Sèvres Brongniart Factory, using various laser excitations. The $406 \mathrm{~nm}$ laser spectra were recorded using macro configuration on the glass support. Similar spectra are obtained with micro configuration on the copper free layer sandwiched between copper-rich ones. The differentiation between K-rich (with 950-1050 to $1090 \mathrm{~cm}^{-1}$ doublet [89]) and Na-rich glass (strong $1090 \mathrm{~cm}^{-1}$ peak [89-91]) is obvious. As noted for the model Eu-containing copper glass, the Raman signature of $\mathrm{Cu}^{\circ}$ containing glass differs strongly from that of the host matrix : the relative intensity of the Si-O bending multiplet vs. the stretching is modified, i.e., the polymerisation index is displaced, indicating that the environment of the metal particle is different from the host matrix. Similar conclusions have been made by S. Pérez et al. for silver-containing yellow glass [28]. Additional bands are observed when analysing the red layers : in many cases the signatures of haematite $\left(\alpha-\mathrm{Fe}_{2} \mathrm{O}_{3}\right)$ with main peaks at 225, 290, 410, 610 and $1310 \mathrm{~cm}^{-1}$ [128] and that of carbon (1350-1600 $\mathrm{cm}^{-1}$ doublet) [4] are observed. The formation of haematite as a result of the $\mathrm{Fe}^{2+}$ ion oxidation in $\mathrm{Fe}^{3+}$ promotes the reduction of copper ions in metal (see equation 8). Obviously the modification of the glass Raman signature is stronger with green excitation than with red one because the red wavelength $(632 \mathrm{~nm})$ is higher than the SPR peak (565 nm, see Fig. 5 and Table 5), which avoids the resonance phenomenon and hence the sensitivity to the metal particle environment. With $532 \mathrm{~nm}$ laser excitation the coupling with the electronic SPR is quasi maximal and in this case the Raman scattering probes only the Si-O bonds 
interacting with the $\mathrm{Cu}^{\circ}$ nanoparticles (Fig. 6). Note that the very strong absorption of the light by $\mathrm{Cu}^{\circ}$ containing glass makes the recording difficult (both the illumination and scattered light are strongly absorbed) and gives rise to green fluorescence which overlaps with the Raman spectrum [100]. Baseline subtraction is required to compare the spectra and this hinders a good measurement of the band intensity, as possible for model glass where the $\mathrm{Cu}$ content is limited and the particle distribution homogeneous [96].

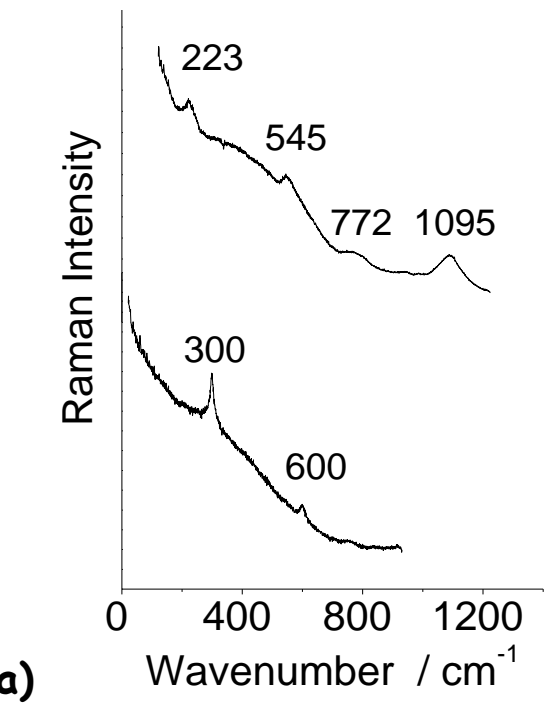

b)

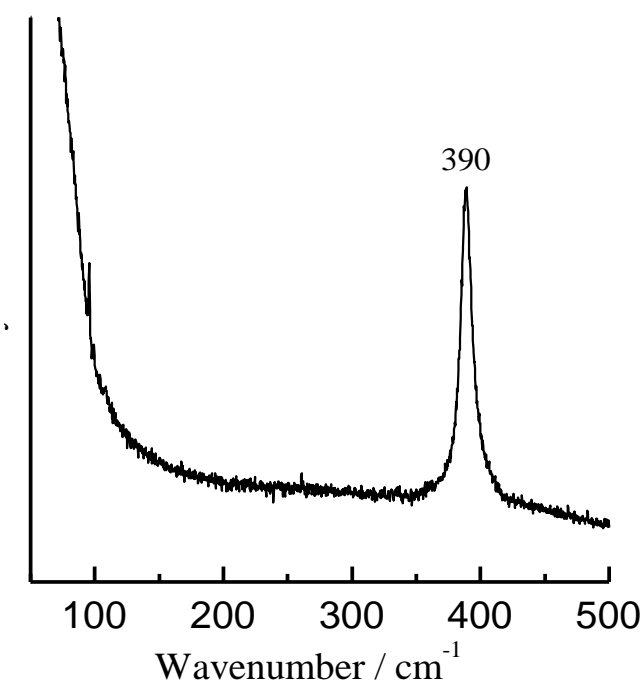

Fig. 8 : a) Raman spectra recorded on the brown "lustre" decor of the bottle depicting a bird (Fig. 2) and on the Arabic inscription [114] of the glass artefacts assigned as Fatimid production (Fig. 2), b) Raman spectrum recorded in some place of a Fatimid lustre pottery, after [37]).

Analysis of the very low wavenumber region $\left(<80 \mathrm{~cm}^{-1}\right)$ allows to characterise the mobile cations having a large polarisability, $\mathrm{Ag}^{+}$and for some extent $\mathrm{Cu}^{+} / \mathrm{Cu}^{2+}$ ions: an example is given in Fig. 6 in model glass and in ancient Fatimids (Fustat) and Abbasid (Suse) lustres [37,96]. Similar spectra have been reported for silver yellow glasses [28]. The assignment of these modes remains subject of some debate: however silver ions can form $\left(\mathrm{Ag}_{\mathrm{n}}\right)^{\mathrm{m+}}$ clusters with mixed ionic and covalent character and the mass effect can displace the wavenumber of the Translational mode toward lower values [96,102,103]. Part of $\mathrm{Cu}$ and $\mathrm{Ag}$ element is however oxidized [29,37]. Some papers however assign the observed low wavenumber features to size effect of $\mathrm{Ag}^{\circ} \mathrm{metal}^{\circ}$ "nanoparticles" [129-132] and ways to discriminate between overlapping contributions remain a source of debate.

Differentiating genuine artifacts and forgery. Fig. 2 shows two glass artefacts, a bottle and a cup, assigned to Fatimids production. Both present some iridescence due to the microcracking of the glass as observed for ancient glasses, especially those recovered from excavations (this iridescence is not sheen and arises from multiple reflections at the glass-air interface). Fig. 8 compares the Raman spectra obtained on the brown lustre: for the glass bottle depicting a bird, a typical Fatimid's topic, a peak at $223 \mathrm{~cm}^{-1}$ is observed although a $300 \mathrm{~cm}^{-1}$ peak (with its overtone at $600 \mathrm{~cm}^{-1}$ ) is recorded on the Arabic inscription of the cup [114]. The latter peak is characteristic of a $\mathrm{CdS}$ phase, a modern chemical compound [133] and the observation of the overtone indicates a resonance spectrum. Actually the brownish colour fits better with that of CdSe and it is not possible to exclude the presence of CdSe mixed with $\mathrm{CdS}$ (the very small peak at $\sim 250 \mathrm{~cm}^{-1}$ corresponds to the signature expected for CdSe [134]). We can thus conclude that at least the Arabic inscription is not original. As noted by Carboni, Pilosi and Wypyski in the Kingery's Series book on Prehistory and History of Glassmaking [135], "the high cost of medieval Islamic gilded and enamelled glass may also have encouraged nineteenth century collectors and glassmakers to 'restore' or 'embellish' authentic pieces". The Raman technique offers some tools to recognize these embellishments and 
restorations. On the contrary the $223 \mathrm{~cm}^{-1}$ peak observed on the bottle corresponds to $\mathrm{As}_{4} \mathrm{~S}_{4}$ [136], a compound used for a long time as a pigment, compatible with the raw materials of the lustre precursor paste. It can be a residue of the sulphur mixture used to produce the lustre.

Obviously, the lustre on glass appears different from the "true" lustre of Abbasid and Fatimids potteries and thus the relation between both techniques claimed by some authors [25,27] may be questioned. The lack of TEM examination does not permit us to go deeper in the discussion. In some places on the lustre glaze (Fig $8 \mathrm{~b}$ gives the example of the Fatimids shard with palmetto decor) a single $390 \mathrm{~cm}^{-1}$ narrow peak is observed [37]. This could correspond to $\mathrm{Pb}_{3} \mathrm{O}_{4}$ [137] but other characteristic components of this compound are not observed. Such single peak may better correspond to a resonance Raman spectrum, of a coloured materials (a sulphur ?). Studies on lustre glass are very rare [85] and this deserves further analyses.

\section{Conclusion}

The review of the present knowledge on ancient materials in which the size and distribution as well as the reduction of copper and silver metal nanoprecipitates were controlled shows the high level of empirical control achieved by ancient potters and glass makers. It is obvious that different routes have been used. The number of studied samples remains limited: for instance no real data are available by TEM for Cassius purple glaze and for red flambé potteries.

\section{Acknowledgments}

The author acknowledges Mrs. A. Hallé, Director of the National Ceramic Museum at Sèvres and I. Pallot-Frossard, Director of LRMH at Champs-sur-Marne for their help as well as colleagues in charge of objects conservation or Art Experts (Mrs M. Bernus-Taylor, M.C. David, V. Milande and MM Ph. Magloire). Drs Ph. Sciau, L. Prinsloo and Prof H. Schreiber are acknowledged for many discussions. The author thanks all under-graduate and $\mathrm{PhD}$ students who experimentally contributed to this work during the past 10 years, especially Drs M.P. Etcheverry, P. Ricciardi and A. Tourniè.

\section{References}

[1] Ph. Colomban: Ceramics Int. Vol. 15 (1989) p23.

[2] Ph. Colomban, Nano/microstructure and Property Control of Single and Multiphase Materials, ch. 12 in Chemical Processing of Ceramics $-2^{\text {nd }}$ Edition, edited by B. Lee and S. Komarneni, (Boca Raton, CRC-Taylor \& Francis, 2005), p303.

[3] B. Mezzadri: Revue de la Céramique et du Verre Vol. 26 (1986) p5. See also I. Chiva and D. Ojalvo: Arts et Traditions Populaires, Vol. 7 (1959) p203.

[4] G. Gouadec and Ph. Colomban: Progress in Crystal Growth \& Characterization Materials Vol. 53 (2007) p1.

[5] G.L Hornyak, C.J. Patrissi, E.B. Oberhauser, C.R. Martin, J.C. Valmette, L. Lemaire, J. Dutta and H. Hofman: Nanostructured Materials Vol. 9 (1997) p 571.

[6] D.J. Barber and I.C. Freestone: Archaeometry Vol. 32 (1990) p33.

[7] H. Bertran, Nouveau Manuel Complet de la Peinture sur Verre, sur Porcelaine et sur Email, (Encyclopédie-Roret, Mulo L. Ed., Paris, 1913).

[8] Ph. Colomban, G. March, L. Mazerolles, T. Karmous, N. Ayed, A. Ennabli and H. Slim: J. Raman Spectroscopy Vol. 34 (2003) p205.

[9] P. Ricciardi, Ph. Colomban, A. Tournié, M. Macchiarola and N. Ayed, submitted to J. Archaeological Science. 
[10] J. Henderson: J. Miner. Met. \& Mater. Soc. (JOM) Vol. 47 (1995) p62; ibidem: Antiquity Vol. 62 (1988) p435; see also P. Costagliola, G. Baldi, C. Cipriani, E. Pecchioni and A. Buccianti: J. Cultural Heritage Vol. 1 (2000) p287.

[11] A. Brongniart, Mémoire sur la Peinture sur Verre (Imprimerie Sellingue, Paris, 1829).

[12] G. Bontemps, Guide du Verrier-Traité historique et pratique de la fabrication des verres, cristaux, vitraux (Librairie du Dictionnaire des Arts Manufacturés, Paris, 1868).

[13] N. Brun, L. Mazerolles and M. Pernot: J. Material Science Letters Vol. 10 (1991) p1418.

[14] Th. Rehren, E.B. Push and A. Herold, Glass coloring works within a copper-centered industrial complex in Late Bronze age Egypt, in: The Prehistory \& History of Glassmaking Technology, edited by P. Mc Cray, Ceramics and Civilization Series Vol. VIII, W.D. Kingery Series Ed. (The American Ceramic Society, Westerville, 1998) p227.

[15] I. Angelini, G. Artioli, P. Bellintani, V. Diella, M. Gemmi, A. Polla and A. Rossi: J. Archaeogical Science Vol. 31 (2004) p1175. G. Artioli, I. Angelini and A. Polla: Phase Transitions Vol. 81 (2008) p233.

[16] I. Nakai, C. Numako, H. Hosono and K. Yamasaki: J. American Ceramic Society Vol. 82 (1999) p689.

[17] N. Wood, Chinese Glazes (University of Pennsylvania Press, Philadelphia, 1999).

[18] W. Qingzheng, A Dictionary of Chinese Ceramics, edited by C. Kelun, J. Song, A. Lau, L. Minghua, N. Yibin, Z. Dong \& Z. Lili, (Sun Tree Publishing Ltd-Oriental Art Publications, Singapore, 2002).

[19] N.Q. Liem, Ph. Colomban, G. Sagon, H.X. Tinh and T.B. Hoanh: J. Cultural Heritage Vol. 4 (2003) p187.

[20] Y.K. Bentor: J. Non-Crystalline Solids Vol. 67 (1984) p433.

[21] C. Mirguet, P. Fredrickx, Ph. Sciau and Ph. Colomban: Phase Transitions Vol. 81 (2008) p253.

[22] Ph. Colomban : La Revue de la Céramique et du Verre Vol. 139 (2004) p 13; see also, L. Franchet: Annales Chimie Physique Vol. 8 (1906) p9; F. Burnham and C.M. Harder: J. American Ceramic Society Vol. 27 (1942) 62; L.A. Holmes: J. Canadian Ceramic Society Vol. 22 (1939) 139; F. Singer and W.L. German, Les Glaçures Céramiques, Ch. 10, p48 (Borax Français, Saint-Germain-en-Laye, 1960).

[23] A. Guinier, Théorie et Technique de la radiocristallographie (Dunod, Paris, 1956) p615.

[24] R. Tilley, Colour and the optical properties of materials (Wiley \& Sons, Chichester, 2000).

[25] S. Carboni, Glass from Islamic Lands-The al-Sabah Collection (Thames \& Hudson, London 2001).

[26] R.H. Brill in: Glass of the Sultans, edited by S. Carboni and D. Whitehouse (Yale University Press, New Haven, 2000).

[27] J. Soustiel, La Céramique Islamique - Le Guide du connaisseur (Office du Livre-Editions Vilo, Paris, 1985). See also J. Moulierac, Céramiques du Monde Musulman (Institut du Monde Arabe-SDZ, Paris, 1989).

[28] S. Pérez-Villar, J. Rubio and J.L. Oteo: J. Non-Crystalline Solids Vol. 354 (2008) p1833. See also F. Rubio, S. Pérez-Villar, M.A. Garrido, J. Rubio and J.L. Oteo, this volume. 
[29] F. Farges, M.P. Etcheverry, A. Scheidegger and D. Grolimund: Applied Geochemistry Vol. 21 (2006) p1715.

[30] G. Marçais, Les faïences à reflets métalliques de la grande mosquée de Kairouan (Geuthner, Paris, 1928).

[31] R.J.B. Mason, Shine like the Sun (Mazda Publishers-Royal Ontario Museum, Toronto, 2004).

[32] S.R. Canby, Islamic Lusterware, in: Pottery in the Making, edited by I. Freestone and D. Gaimster (British Museum Press, London, 1977).

[33] A. Caiger-Smith, Luster Pottery - Technique, Tradition and Innovation in the Islam and the Western Worlds (Faber \& Faber, London, 1991).

[34] O. Watson, Ceramics from Islamic Lands (Thames \& Hudson, New-York. 2004).

[35] J. Pérez-Arantegui, J. Molera, A. Larrea, T. Pradell, M. Vendrell-Saz, I. Borgia, B.G. Brunetti, F. Cariati, P. Fermo, M. Mellini, A. Sgamellotti and C. Vitti: J. American Ceramic Society Vol. 84 (2001) p442.

[36] S. Padovani, C. Sada, P. Mazzoldi, B.G. Brunetti, I. Borgia, A. Sgamellotti, A. Giulivi, F. d'Acapito and G. Battaglin: J. Applied Physics Vol. 93 (2003) p10058.

[37] Ph. Colomban and C. Truong: J. Raman Spectroscopy Vol. 35 (2004) p195.

[38] G. Padeletti and P. Fermo: Applied Physics A Vol. 79 (2004) p241.

[39] I. Borgia, B. Brunetti, I. Mariani, A. Sgamelotti, F. Cariati, P. Fermo, M. Mellini, C. Vitti and G. Padeletti: Applied Surface Science Vol. 185 (2002) p206.

[40] I. Borgia, B. Brunetti, A Giulvi, A. Sgamellotti, F. Shokouhi, P. Olialy, J. Rahighi, M. Lamehi-Rachti, M. Mellini and C. Vitti: Appl. Phys. A Vol. 79 (2004) 257.

[41] J. Roqué, T. Pradell, J. Molera and M. Vendrell-Saz: J. Non-Crystalline Solids Vol. 351 (2005) p568.

[42] P. Mazzoldi and C. Sada: Materials Science \& Engineering B Vol. 149 (2008) 112.

[43] J. Roqué, J. Molera, P. Sciau, E. Pantos and M. Vendrell-Saz: J. European Ceramic Society Vol. 26 (2006) p3813.

[44] T. Pradell, J. Molera, A.D. Smith and M.S. Tite: J. Archaeological Science Vol. 35 (2008) p1205.

[45] D. Chabanne, O. Bobin, M. Schvoerer, C. Ney and Ph. Sciau, in Proceedings of $34^{\text {th }}$ International Symposium on Archaeometry. Publicacion numero 2.621 de la Institucion «Fernando el Catolico» (Excma Diputacion de Zaragoza 2006) p 427.

[46] J. Pérez-Arantegui and A Larrea: TrAC-Trends in Analytical Chemistry Vol. 22 (2003) p327.

[47] J. Roqué, J. Molera, G. Cepria and M. Vendrell-Saz: Phase Transitions Vol. 81 (2008) p267.

[48] J. Roqué, J. Molera, J. Pérez-Arantegui, C. Calabuig, J. Portillo and M. Vendrell-Saz: Archaeometry Vol. 49 (2007) p511.

[49] G. Cepria, J. Roqué, J. Molera, J. Pérez-Arantegui and M. Vendrell-Saz: Electroanalysis Vol. 19 (2007) p1167.

[50] E. Darque-Ceretti, D. Helary, A. Bouquillon, M. Aucouturier and G. Monge: Surface Engineering Vol. 21 (2005) p352.

[51] A. Galli, M. Martini, E. Sibilia and G. Padeletti: Applied Physics A-Materials Science \& Processing Vol. 79 (2004) p293. 
[52] G. Padeletti and P. Fermo: Applied Physics A-Material Science \& Processing Vol. 76, (2003) p515.

[53] P. Fermo, F. Cariati, C. Cipriani, M. Canetti, G. Padeletti, B. Bruneti and A. Sgamellotti: Applied Surface Science Vol. 185 (2002) p309.

[54] A.D. Smith, T. Pradell, J. Roqué, J. Molera, M. Vendrell-Saz, A.J. Dent and E. Pantos: J. Non-Crystalline Solids Vol. 352 (2006) p5353.

[55] E. Bontempi, P. Colombi, L.E. Depero, L. Cartechini, F. Presciutti, B.G. Brunetti and A. Sgamellotti: Applied Physics A-Materials Science \& Processing Vol. 83 (2006) p543.

[56] S. Padovani, I. Borgia, B. Brunetti, A. Sgamellotti, A. Giulivi, F. d'Acapito, P. Mazzoldi, C. Sada and G. Battaglin: Applied Physics A-Materials Science \& Processing Vol. 79 (2004) p229.

[57] O. Bobin, M. Schvoerer, C. Ney, M. Rammah and A. Daoulatli: Archaeometry Vol. 45 (2003) p569.

[58] O. Bobin, M. Schvoerer, C. Ney, B. Pannequin, E. Cilia Platamone, A. Daoulatli and R.P. Gayraud: Color Res. \& Appl. Vol. 28 (2003) p352.

[59] F. Colao, R. Fantoni, V. Lazic and V. Spizzichino: Spectrochemica. Acta Part B Vol. 57 (2002) p1219.

[60] G. Padeletti and P. Fermo: Applied Physics A-Materials Science \& Processing Vol. 77 (2003) p125.

[61] P. Vukovic, B. Hallam and J. Noyes: Science Vol. 315 (2007) p348.

[62] V.L. Welch and J.P. Vigneron: Optic Quantum Electronics Vol. 39 (2007) p295.

[63] D.J. Brink, N.G. van der Berg, L.C. Prinsloo and I.J. Hodgkinson: J. Physics D Applied Physics Vol. 40 (2007) p2189.

[64] D.J. Brink and M.E. Lee: Applied Optics Vol. 38 (1999) p5282.

[65] V. Reillon, S. Berthier and S. Chenot, Physica B: Condensed Mater Vol. 394 (2007) p238.

[66] H.D. Schreiber, M.A. Stone and A.M. Swink: J. Non-Crystalline Solids Vol. 352 (2006) p534.

[67] M. Walker: The Advanced Semi-Conductor Magazine Vol. 18 (2005) p46.

[68] E.V. Vogel: J. American Ceramic Soc. Vol. 72 (1989) p719.

[69] O. Bobin, M. Schvoerer, J.L. Miane and J.F. Fabre: J. Non-Crystaline Solids Vol. 332 [2003) p28.

[70] $\mathrm{Ph}$. Colomban and V. Vendange, Sol-gel routes towards magnetic nanocomposites with tailored microwave absorption, in: V-Nanophase and Nanocomposite Materials II, edited by S. Komarnemi, J.C. Parker JC and H.J. Wollenberger (MRS Fall Meeting Proc. Vol. 457 (1997) p451.

[71] V. Vendange and Ph. Colomban: Materials Science and Engineering, A Vol. 168 (1993) p199.

[72] V. Vendange, F. Flavin and Ph. Colomban: J. Materials Science Letters Vol. 15 (1996) p137.

[73] G. De, L. Tapfer, M. Catalano and G. Battaglin: Applied Physics Letters Vol. 68 (1996) p 3820 .

[74] Z. Szabo, G. Kadar and J. Balazs: Current Applied Physics Vol. 6 (2006) p149. 
[75] U. Kreibig and M. Vollmer, Optical Properties of Metal Cluster (Springer, Berlin, 1995).

[76] L. B. Hunt: Gold Bulletin Vol. 9 (1976) p134.

[77] W. Lewis, Glass and Enamel by Preparations of Gold, Commercium PhilosophicoTechnicum; or, The Philosophical Commerce of Arts: Designed as an Attempt to Improve Arts, Trades, and Manufactures (London, 1763), p170. On the Bolognese manuscript, see Mary P. Merrifield, Medieval and Renaissance Treatises on the Arts of Painting (1849; reprint, New York, 1967), p334.

[78] Abû al-Qâsem Kâshâni, Arâyes al-javâher, edited by I. Afshâr, (Teheran, 1966). Translation by J.W. Allan, Abû'l-Qâsim's Treatise on Ceramics: Iran Vol. 11 (1973) p111.

[79] Y. Porter, Les techniques du lustre métallique d'après le Jowhar-Nâme-ye-Nezâm (1196), Actes du VIIe Congrès International sur la Céramique Médiévale en Méditerranée, Thessaloniki, 11-16 October 1999 (Caisse des Recettes Archéologiques, Athènes 2003), p427.

[80] C. Picolpasso, Li Tre Libri dell'Arte del Vasaio, 1557, first translated and edited by C. Popelin, Les trois Livres de l'Art du Potier, (Paris, 1881). See also The Three Book of the Potter's Art, La Revue de La Céramique et du Verre, Fac-Similé Edition, 2007

[81] Anonymous, El Lapidario del Rey Alphonso X, translation in Spanish by King Alfonso in the year 1279, see in N. Heaton: J. British Society of Master Glass-Painters Vol. 48 (1947) p9.

[82] Th. Deck, La Faïence, (Maison Quantin, Paris, 1887).

[83] L.A. Salvetat, Leçons de Céramiques professées à l'Ecole Centrale des Arts et Manufactures, (Malet-Bachelier, Paris, 1857).

[84] J.L. Artigas, Formulario y practica de ceramica (Ediciones Omega, 1992, Barcelona, 1992; $1^{\text {st }}$ Edition 1950).

[85] T. Sawada, A. Hokura, I. Nakai and Y. Shindo, in Annales du 16e Congrès de l'Association Internationale pour l'Histoire du Verre -AIHV-16, London 2003 (AIHV, Nottingham, 2005).

[86] G. Padeletti and P. Fermo: Applied Physics A79 (2004) p277.

[87] S. Padovani, D. Puzzovio, C. Sada, P. Mazzoldi, I. Borgia, A. Sgamellotti, B.G. Brunetti, L. Cartechini, F. d'Acapito, C. Maurizio, F. Shokoui, P. Oliaty, J.A. Rahighi, M. Lamehi-Rachti, and E. Pantos: Applied Physics A Vol. 83 (2006) p521.

[88] Ph. Colomban: J. Non-Crystalline Solids Vol. 323 (2003) p180.

[89] Ph. Colomban, A. Tournié and L. Bellot-Gurlet: J. Raman Spectroscopy Vol. 37 (2006) p841.

[90] A. Tournié and Ph. Colomban: J. Cultural Heritage Vol. 8 (2007) p242.

[91] Ph. Colomban, M.-P. Etcheverry, M. Asquier, M. Bounichou and A. Tournié: J. Raman Spectroscopy Vol. 37 (2006) p614.

[92] Ph. Colomban and V. Milande: J. Raman Spectroscopy Vol. 37 (2006) p606.

[93] Ph. Colomban, Th. Calligaro, Cl. Vibert-Guigue, N. Q. Liem and H.G.M. Edwards: Revue d'Archéométrie-Archéosciences Vol. 29 (2006) p7.

[94] Th. Calligaro: X-ray Spectrometry Vol. 37 (2008) p169.

[95] Reflets d'or-D'Orient en Occident, la céramique lustrée IX-XVe siècle, Catalogue, Musée de Cluny-Musée National du Moyen Age (RMN, Paris, 2008).

[96] Ph. Colomban and H. Schreiber: J. Raman Spectroscopy Vol. 36 (2005) p884. 
[97] P. Fredrickx, J. Verbeeck, D. Schryvers, D. Helary and E. Darque-Ceretti: Nanoparticles in lustre reconstructions, 7th Symposium on Materials Issues in Art and Archaeology, 2004 MRS Fall Meeting Proc., Materials Issues in Art \& Archaeology VII Vol. 852 (2005) p169.

[98] Ph. Sciau, E. Haudum and Ph. Colomban, to be published.

[99] S. Qu, Y. Gao, X. Jiang, H. Zeng, Y. Song, J. Qiu, C. Zhu and K. Hirao: Optics Communications Vol. 224 (2003) p321.

[100] Ph. Colomban, P. Ricciardi and A. Tournié, submitted to the J. of Raman Spectroscopy.

[101] V. Bakumov, K. Gueinzius, C. Hermann, M. Schwarz and E. Kroke: J. European Ceramic Society Vol. 27, (2007) p3287.

[102] Ph. Colomban, R. Mercier and G. Lucazeau: J. Chem. Phys. Vol. 75 (1981) p1388.

[103] Ph. Colomban G. Lucazeau and A. Novak: J. Phys. C (Solid State Physics) 14, (1981) 4325.

[104] J. Henderson, Post-medieval glass : production, characterization and value in: The Prehistory and History of Glassmaking Technology, edited by P. McCray, Ceramics and Civilization Series, W.D. Kingery Series Ed. Vol. VIII (The American Ceramic Society, Westerville, 1998) p 33-59.

[105] J. Mass, A. Ammerman and J.A. Hunt Archeological Exploration with the Electron Microprobe in: The Early History of Glassmaking in the Venetian Lagoon (American Laboratory, 2001) p52.

[106] I.C. Freestone and C.P. Stapleton, Composition and Technology of Islamic enamelled glass of the 13-14 ${ }^{\text {th }}$ centuries (ch 24) in: Gilded and Enamelled Glass from the Middle East, edited by R. Ward (British Museum Press, London, 1998).

[107] H.D. Schreiber and A.L. Hockman: J. American Ceramic Society Vol. 70 (1987) p591.

[108] H.D. Schreiber and M.E. Stokes: The Glass Researcher, Vol. 11 (2001) p13.

[109] H.D. Schreiber, B.K. Kochanowski, C. W. Schreiber, A.B. Morgan, M.T. Coolbaugh and T.G. Dunlap: J. Non-Crystalline Solids Vol. 177 (1994) p340.

[110] H.D. Schreiber, M.E. Stokes and A.M. Swink: Ceramic Transactions Vol. 141 (2004) p315.

[111] J.P. Malins and K.H. Tonge: Thermochimica Acta Vol. 340-341(1999) p395.

[112] E. Hundun, La Lettre Sfeco Mars $2007 \mathrm{n}^{\circ} 11$, (May 2008), http://www.ladir.cnrs.fr/Ceramic2004/file/SF11.pdf,

[113] S. Greiff and J. Schuster: J. Cultural Heritage Vol 9 Suppl. 1 (2008) pe27.

[114] P. Ricciardi, Ph. Colomban, A. Tournié and V. Milande, J. Raman Spectroscopy Vol. 39 (2009); doi:10.1002/jrs.2165.

[115] Y.F. Yao and J.T. Kummer: J. Inorganic Nuclear Chemistry Vol. 29 (1967) p2453.

[116] H.M. Garfinkel: J. Physical Chemistry Vol. 72 (1968) p4175.

[117] T. Pradell, J. Molera, J. Roqué, M. Vendrell-Saz, A.D. Smith, E. Pantos and D. Crespo: J. American Ceramic Society, Vol. 88 (2005) p1281.

[118] Ph. Sciau, C. Mirguet, C. Roucau, D. Chabanne, M. Schwoerer: J. NanoResearch, this volume.

[119] J.P. Van Lith, La Céramique,-Dictionnaire Encyclopédique (Les Editions de l'Amateur, 2000), pp 247-251.

[120] Ph. Colomban: L'Industrie Céramique Vol. 697 (1976) p531. 
[121] A. Caiger-Smith: La Revue de la Céramique et du Verre, 161 (2008) p32.

[122] G. Gouadec and Ph. Colomban, J. Raman Spectroscopy Vol. 38 (2007) p598.

[123] L. Raffaëlly, B. Champagnon, N. Ollier and D. Foy: J. Non-Crystalline Solids Vol. 354 (2008) p780.

[124] E. Malchukova, B. Boizot, D. Ghaleb and G. Petite: J. Non-Crystalline Solids Vol. 352 (2007) p297.

[125] I. Halasz, M. Agarwal, R. Li and N. Miller: Catalysis Today Vol. 126 (2007) p196.

[126] C. Ricci, C. Miliani, F. Rosi, B. G. Brunetti and A. Sgamellotti: J. Non-Crystalline Solids, 353, (2007) 1054-1059.

[127] N. Ollier, T. Charpentier, B. Boizot, G. Wallez and D. Ghaleb: J. Non-Crystalline Solids Vol. 341 (2004) p26.

[128] F. Froment, A. Tournié and Ph. Colomban: J. Raman Spectroscopy Vol. 39 (2008) p560.

[129] F. Pérez-Robles, F.J. Garcia-Rodriguez, S. Jimenez-Sandoval and J. Gonzalez-Hernandez, J. Raman Spetroscopy Vol. 30 (1999) p1099.

[130] J. Qiu, M. Shirai, T. Nakaya, J. Si, X. Jiang, C. Zhu and K. Hirao: Applied Physics Letters Vol 81 (2002) p3040.

[131] M. Ferrari, F. Gonella, M. Montagna and C. Tosello: J. Applied Physics Vol. 79 (1996) p2055.

[132] P. Gangopadhyay, R. Kesavamoorthy, K.G.M. Nair and R. Dhandapani: J. Applied Physics Vol. 88 (2000) p4975.

[133] H.M. Fan, Z.H. Ni, Y.P. Feng, X.F. Fan, Z.X. Shen and B.S. Zou: J. Raman Spectroscopy Vol. 38 (2007) p1112.

[134] H. Rho, L.M. Smith, H.E. Jackson, S. Lee, M. Dobrowolska and J.K. Furdyna: physica status solidi Vol. 224 (2001) p165.

[135] S. Carboni, L. Pilosi and M.T. Wypyski, A gilded and enamelled glass plate in the Metropolitan Museum of Art, in: Prehistory and History of Glassmaking Technology, edited by P. McCray, Ceramics and Civilization Series, W.D. Kingery Series Editor Vol. VIII, (The American Ceramic Society, Westerville 1998) p79-102.

[136] W. Bues, M. Sommer and W. Brockner: Z. anorganische allgemeine Chemie Vol. 499 (1983) p7.

[137] A. Kaminska, M Sawczak, M Oujja, C Domingo, M Castillejo and G Sliwinski: J. Raman Spectroscopy Vol. 37 (2006) p1125. 